\title{
GEOGRAFIA, FRONTEIRA DO MUNDO: ENSAIO SOBRE POLÍTICA, EPISTEMOLOGIA E HISTÓRIA DA GEOGRAFIA
}

\author{
GUILHERME RIBEIRO ${ }^{1}$ \\ Universidade Federal Rural do Rio de Janeiro
}

\begin{abstract}
Resumo: Este texto pretende ser o esboço de uma reflexão acerca da epistemologia e da história da Geografia sob a égide da política explorando a hipótese segundo a qual a Geografia universitária já surgiu como geopolítica. Tal razão explicaria o fato de que ela tem sido uma das principais responsáveis por forjar uma imagem fronteiriça de mundo, com a linguagem cartográfica assumindo papel de destaque nessa operação. Faz-se necessário, portanto, uma interpretação crítica da epistemologia e da história da Geografia, algo ensaiado por intermédio das contribuições oriundas do pós-colonialismo.
\end{abstract}

Palavras-chave: Geografia; Epistemologia; Política; Fronteira; Pós-colonialismo.

\footnotetext{
${ }^{1}$ Doutor em Geografia pela UFF, com estágio doutoral pela Universidade de Paris-Sorbonne (Paris IV). Pós-Doutor em Geografia pela UFMG. Professor do Programa de Pós-Graduação em Geografia da UFRRJ. Artigo elaborado com auxílio da FAPERJ e do PIBIC/CNPq/UFRRJ no âmbito das atividades do nosso Laboratório Política, Epistemologia e História da Geografia (LAPEHGE/UFRRJ). Redigido para a mesa-redonda "Espaço, região e território: pressupostos teórico-metodológicos”, ocorrida no I colóquio baiano Tempos, espaços e representações: abordagens geográficas e históricas na UESB (outubro 2013), e ampliado para a mesa "Fundamentos teóricometodológicos da pesquisa geográfica” no âmbito do I Seminário Integrado de Pesquisa, Ensino e Extensão em Geografia na UNEB-Serrinha (setembro 2014). Agradeço enormemente a gentileza do convite ao colega Renato Léda, professor desta instituição e um dos organizadores dos eventos. Versões preliminares desse texto foram lidas (na sequência) por Felipe Ramão, Federico Ferretti, André Santos da Rocha, Lara D’Assunção dos Santos, Rodrigo Corrêa Teixeira e Paul Claval, a quem agradecemos imensamente pelas observações tão gentis quanto pertinentes. Com seus questionamentos, nossos alunos das disciplinas História do Pensamento Geográfico e Geopolítica na UFRRJ também ajudaram a forjar esse artigo. Somos gratos ainda ao professor Cássio Eduardo Viana Hissa por todo o aprendizado durante nosso estágio pós-doutoral na UFMG. Nenhum deles possui qualquer encargo sobre o conteúdo apresentado. Contato: geofilos@ig.com.br.
} 


\title{
GEOGRAPHY, BOUNDARY OF THE WORLD: AN ESSAY ON POLITICS, EPISTEMOLOGY AND THE HISTORY OF GEOGRAPHY
}

\begin{abstract}
This article intends to be an exploratory reflection on epistemology and history of geography under the auspices of politics. Our hypothesis is that academic geography was born as geopolitics. For that reason, it has at the forefront of forging a border depiction of the world, including the crucial role played by cartographic language. A critical interpretation of epistemology and history of geography is thus needed, and this is what the article attempts to do with the support of postcolonial theory.
\end{abstract}

Keywords: Geography; Epistemology; Politics; Boundary; Postcolonialism.

\section{Introdução}

A ocasião para escrevermos algumas notas sobre a história e a epistemologia da Geografia é bastante apropriada, uma vez que o campo científico como um todo tem sido significativamente alterado diante das inúmeras possibilidades abertas pelas interrogações disciplinares e interdisciplinares acentuadas nas últimas quatro décadas. Com efeito, categorias tradicionalmente associadas a um determinado campo passam a receber influências de outros, conduzindo a uma interessante releitura conceitual e, de modo geral, a um questionamento de natureza teórica. Alguns admitem mesmo uma "transição paradigmática" e, neste movimento, a Geografia teria muito a dizer ${ }^{2}$. Além disso, outro fator diz respeito ao fato de que o final do século XX presenciou mudanças históricas de relevo, com realce para o término da Guerra Fria, a rapidez e a disseminação das inovações técnicocientíficas e o fenômeno da globalização. Em suma, as dinâmicas científicas e sócio-históricas - separação meramente didática - convergem, de certa forma, no sentido de que profundas modificações espaciais as afetaram.

As linhas a seguir pretendem explorar a dimensão política da ciência geográfica à luz da história e da epistemologia, tendo como inspiração os aportes oriundos do pós-colonialismo. Permeia nosso texto um olhar endereçado à constituição política da Geografia, saber indissociável da geopolítica e cujos desdobramentos resultaram na criação de uma cultura de fronteira, na qual mapas e imagens tiveram papel basilar na operação de classificação dos espaços do mundo.

\footnotetext{
${ }^{2}$ Nas palavras do pensador Boaventura de Sousa Santos, o "relativo desaparecimento das distinções dicotômicas tem repercussões nas disciplinas científicas que delas nasceram. Aliás, sempre houve ciências que se reconheceram mal nestas distinções, de tal modo que tiveram de se fraturar internamente para se lhes adequarem minimamente. Refiro-me à Antropologia, à Geografia e também à Psicologia. Mais do que em quaisquer outras, condensaram-se nelas privilegiadamente as contradições da separação entre ciências naturais e ciências sociais. Daí que, neste período de transição paradigmática, seja particularmente importante, do ponto de vista epistemológico, observar o que se passa nessas ciências" (SANTOS, 2007, p. 90 [2000], grifo nosso. Na verdade ele retoma ipsislitteris, esse trecho de seu clássico Um discurso sobre as ciências (SANTOS, 2010, p. 64-65 [1987]).
} 
Assim, a seção inicial deste trabalho recupera os fundamentos da moderna Geografia universitária a partir de três elementos: cartografia, geopolítica e fronteira. Em seguida, enfatiza-se a relevância do pós-colonialismo como possibilidade de abordar a história da Geografia para além de suas versões mais difundidas (BUTTIMER, 1980 [1971]; LACOSTE, 1988 [1976]; MORAES, 1999 [1981]; CAPEL, 1981; CLAVAL, 1998; ROBIC, 2006). Embora a relevância de tais trabalhos seja inegável, eles acabaram por transmitir a noção de que a história da Geografia é, essencialmente, a história de conceitos, ideias e autores, tendo a dimensão política e colonial que, a nosso ver, estruturou a Geografia moderna, assumido lugar secundário ${ }^{3}$. A parte final pretende reunir elementos capazes de promover uma crítica embrionária à história da Geografia.

\section{Cartografia, geopolítica, fronteira: fundamentos da moderna Geografia universitária}

Tais questões definem os fios condutores do presente artigo: as relações entre Geografia, política e epistemologia. De que formas podemos promover uma reflexão sobre a Geografia e o espaço, ou seja, sobre os instrumentos que auxiliaram na "fronteirização" do mundo, em termos de uma crítica da modernidade? Que o leitor nos conceda permissão a tal neologismo, já que os vocábulos delimitar, demarcar e grafar, a despeito de sua força, não trazem consigo a tensão, o choque, a fricção contidas no termo fronteira. Nesse sentido, tem toda razão Carlos Walter Porto-Gonçalves, para quem a Geografia carece muito mais de ser verbo que substantivo ou adjetivo. Ou seja, a Geografia é, antes de mais nada, ação, prática, intervenção no mundo (PORTO-GONÇALVES; RIBEIRO, 2011).

Isso nos faz pensar que ainda não cultivamos a contento a questão referente ao fato de a Geografia ser uma das principais responsáveis por criar espaços, regiões e territórios, ou seja, por fragmentar e separar o mundo, fronteirizando-o. Ao sugerirmos que a Geografia cria o mundo e sua imagem como algo incontornavelmente fronteiriço, queremos destacar o duplo sentido do verbo utilizado, isto é, ela cria no sentido de engendrar, mas, simultaneamente, acredita naquilo que inventa. Poderíamos ir além e apontar que um terceiro elemento da démarche geográfica seria o de convencer - e, portanto, reproduzir - , em termos

\footnotetext{
${ }^{3} \mathrm{O}$ caso de A geografia - isso serve, em primeiro lugar, para fazer a guerra (1976), aparentemente, parece não enquadrar-se nesta observação. Todavia, embora aponte para a centralidade da política e da estratégia, Lacoste não as reconhece na "Escola Francesa de Geografia” que, segundo ele, rejeitou os fenômenos geopolíticos. Esta interpretação é absolutamente contraditória em relação ao envolvimento e à produção intelectual dos geógrafos franceses sobre o colonialismo, tal como apontaremos no decorrer deste artigo.
} 
universais, que aquela concepção de mundo é única, coerente e precisa. Tal raciocínio dissimula o que não passa de uma possibilidade monotópica, que faz questão de desmerecer os inúmeros lócus de enunciação existentes nas culturas e nas línguas fora da Europa (cf. MIGNOLO, 2003, p. 103 [2000]).

Todavia, por força da arquitetura imperialista da modernidade, acabamos por nos persuadir da inexistência de outra imagem senão a que nos foi transmitida. A síntese dessa Geografia é o mapa de Mercator, que se apropriou do mundo e, em seu âmago, instaurou a face da Europa. Tal mapa não deixa de ser a forma como a própria Europa projetou-se diante do mundo: como soberana. Seus valores foram reproduzidos como se fossem globais (RIBEIRO, 2012). Por tais razões, ainda temos dificuldade em imaginar a Geografia, o espaço e o mundo de outra forma. No entanto, é necessário projetar outra imagem; é preciso imaginar outro projeto. A opção pelo verbo imaginar não é acidental e as palavras imaginário e imagem tampouco dividem o mesmo radical por coincidência: imaginário é o conjunto de imagens formadas por nossos preconceitos, julgamentos de valor, visões de mundo, ideologias, culturas. Se o imaginário é o pensar (e pensar com imagens, isto é, imaginar), então pensar é algo, essencialmente, geográfico. Nesse contexto, se Anibal Quijano tem razão ao certificar que "o próprio imaginário foi, demonstradamente, colonizado” (QUIJANO, 2010, p. 124 [2000]), então cabe à Geografia o papel ímpar de subverter tal imaginário.

A despeito dos mapas serem documentos preciosos em termos estéticos e representacionais, é inegável que eles são uma mirada hegemônica acerca da natureza, do território e da história. O geógrafo incumbiu-se de consagrar a imagem de um mundo fronteiriço e territorial - incluídas aqui as tão conhecidas e celebradas personagens do estrangeiro, do conquistador, do patriota, do nacionalista. As pessoas e suas experiências, seus modos de vida, culturas e saberes, não raro, são deslocadas. Tudo isso nos faz concluir que a linguagem cartográfica é uma linguagem-força que sufocou outras representações espaciais. Esta operação não se deu ao acaso, mas, sim porque beneficiava a construção de uma dada hegemonia que precisava ser fortalecida.

John Brian Harley destaca bem os múltiplos poderes contidos (e ocultos) nos mapas:

Enquanto um tipo de conhecimento impessoal, os mapas tendem a 'dessocializar' o território que representam. Eles favorecem a noção do espaço socialmente vazio. A qualidade abstrata do mapa, incorporada tanto nas linhas da projeção ptolomaica do século XV quanto nas imagens contemporâneas da cartografia informatizada, atenua a tomada de consciência de que os seres vivos vivem na paisagem. As decisões relativas ao exercício do poder estão desconectadas do domínio dos contatos interpessoais (HARLEY, 2013, p. 23 [1988]). 
Enfim, o que era apenas uma projeção a Europa impôs como verdade absoluta. Por este e outros motivos as noções de verdade e de razão passaram a ser objeto de tamanho escrutínio (REIS, 2005). Elaborada pela Filosofia num primeiro momento e, a partir do século XIX, pelas Ciências Humanas, esta concepção instrumental da razão fez da diversidade espacial dos agrupamentos humanos territórios nacionais identitários; da multiplicidade de ritmos e tempos históricos, uma narrativa linear do progresso; da heterogeneidade cultural, a cisão barbárie-civilização. Em síntese, a razão e a ciência modernas homogeneizaram o mundo e, ao mesmo tempo, hierarquizaram-no, coroando a Europa em seu cerne. Homogeneização e hierarquização representam o triunfo político do espaço cartesiano-newtoniano. Ele legitima toda e qualquer intervenção de cima para baixo, pois com ele os sujeitos tornam-se meros pontos no espaço, objetos de uma Antropologia, Sociologia, História e Geografia obedientes à lógica da eficiência, da maximização e da racionalização instrumental do mundo.

Personagem essencial no estabelecimento da disciplina Geografia na GrãBretanha e autor do célebre ensaio The geographical pivot of history (MACKINDER, 2004 [1904]), Halford John Mackinder tinha plena consciência dessa situação. Não por acaso, destacava a utilidade “pedagógica” da Geografia em termos estratégicos, tendo em vista sua capacidade de fomentar - por meio de mapas, fotos e slides - as habilidades de observação dos mais jovens. Uma vez que conhecer um império mundial como o britânico exigia "amplos poderes de visualização” (MACKINDER, 1911, p. 84. Ver também MACKINDER, 1942, p. 124-125), criou-se em 1902 o Visual Instruction Committee of the Colonial Office, a fim de realizar livros educativos e conferências ilustrados por projeções de slides para uso nas escolas do Reino Unido e das colônias do Ceilão, Hong Kong, Ilhas Maurício, Serra Leoa, Costa do Ouro (atual Gana), Sul da Nigéria, Trinidad, Guiana, Sudeste Asiático (as quatro Straits Settlements), Jamaica e várias províncias da Índia. Ou seja, a manipulação das imagens metropolitanas e coloniais pela Geografia (e, portanto, do olhar), transformando-as em paisagens, era um plano imperial — não apenas da Inglaterra, mas também da França ${ }^{4}$.

Por conseguinte, ao abordarmos os pressupostos epistemológicos da Geografia e de seus conceitos, é preciso, antes de tudo, suspeitar da ciência e da razão tal como

\footnotetext{
${ }^{4}$ Sobre o caso britânico e a participação de Mackinder nessa questão, consulte Ryan (RYAN, 1994). A respeito da França, fundada em 1821 em Paris, a Société de géographie também tinha enorme interesse nas explorações e nas imagens delas resultantes. Patrocinadora do colonialismo, uma seleção de seu inventário fotográfico foi compilada em Trésors photographiques de la société de géographie (LOISEAUX, 2007). Não dirá Daniel Clayton que "muito do que o público europeu conhecia do mundo imperial provinha das sociedades de geografia”? (CLAYTON, 2011, p. 6). Sabemos também como as paisagens e sua mimetização em recortes locais e regionais foram amiúde exploradas em nome dos Estados Nacionais europeus desejosos de identidade, coesão e unidade (VIDAL DE LA BLACHE, 2007 [1903]; WALTER, 2004).
} 
as conhecemos. Do contrário, não estaremos nós, implicitamente, recorrendo a uma apologia das geografias hegemônicas de poder? Ao mencionarmos os conceitos geográficos, não é incomum a sensação de lidar com espaços sem subjetividade, sem sujeitos, sem discussão. Eles estão lá, isto é, fora de nós, dados, prontos. Não há nada a fazer, a problematizar.

No livro A invenção do Nordeste e outras artes, a arguta crítica perpetrada por Durval Muniz de Albuquerque Júnior interroga a fundo tal estado de coisas. Neste caso, a condição de historiador fez toda diferença, pois ele não estava tolhido pelo manto do corporativismo e, a despeito de ligeiras simplificações ao redor da abordagem regional em Geografia (compreensíveis, diga-se, pois elas foram essenciais para que ele levasse adiante o núcleo de sua argumentação), ele quis inquirir

a história da emergência de um objeto de saber e de um espaço de poder: a região Nordeste (...). O Nordeste nasce onde se encontram poder e linguagem, onde se dá a produção imagética e textual da espacialização das relações de poder. Entendemos por espacialidade as percepções espaciais que habitam o campo da linguagem e se relacionam diretamente com um campo de forças que as institui. Neste trabalho, o geográfico, o linguístico e o histórico se encontram, porque buscamos analisar as diversas linguagens que, ao longo de um dado processo histórico, construíram uma geografia, uma distribuição espacial dos sentidos (ALBUQUERQUE JR, 2009, p. 33 [1999], grifo nosso).

No rastro de sua percepção - cuja inspiração foucaultiana também compartilhamos e, não por coincidência, o pensador francês manifestou notório interesse pelas questões espaciais (FOUCAULT, 1976, 1979, 1984) —, deparamonos com uma situação muito reveladora sobre essa Geografia que cristaliza espaços e naturaliza sujeitos: se é indiscutível que geógrafos têm promovido a fronteirização do mundo, sendo tal fronteirização elemento constituinte da própria Geografia que se impôs ao globo e ao nosso espírito, como explicar a escassez de debates em torno da fronteira no interior da própria Geografia? Claro está que não estamos nos referindo ao conceito (embora ele tenha sido menos explorado que região, paisagem ou espaço) ou às pesquisas empíricas, mas à fronteira como raison d'être da disciplina, seu leitmotiv.

Enfim, se acreditarmos na necessidade de rever as maneiras pelas quais a história e a epistemologia do pensamento geográfico têm sido concebidas, nosso hipotético ponto de partida pode ser então esboçado pela máxima de que $a$ moderna Geografia universitária já surge geopolítica, tendo como fundamento a edificação de fronteiras. Talvez esta seja uma forma de compreender a natureza do conhecimento espacial em voga no Ocidente. Afinal, um saber institucionalizado 
como obra do Estado, possuidor de apelo econômico na consecução de empreendimentos liberais e que opera nomeando lugares, forjando regiões e demarcando territórios, decerto precisa ignorar que um de seus conceitos-chave é, exatamente, fronteira. É uma forma de amenizar a tensão existente entre o eu e o outro, a identidade e a diferença, o encontro e o desencontro, o incluído e o excluído. No fundo, desconhecer a fronteira como origem e condição da Geografia significa dissimular a artificialidade e a política desta própria Geografia. Não teria sido desta forma que ela se organizou e adentrou nas universidades europeias no decorrer da segunda metade do século XIX, ${ }^{5}$ como um discurso em torno da demarcação dos Estados Nacionais europeus; como estratégia de dominação e de legitimação das metrópoles sobre as colônias; como apologia ao solo, ao clima, ao relevo, à vegetação e à hidrografia, transmutados em paisagens e territórios pátrios circunscritos por fronteiras notadamente postiças?

Assimilada desta maneira, a Geografia apresenta-se como uma espécie de mito: muitas vezes, os espaços por ela representados só fazem sentido para um único grupo e, não raro, assumem forte conotação metafísica. São assim os apelos de Friedrich Ratzel e de Paul Vidal de La Blache: o solo (boden) e o território (sol) seriam imantados, dotados de particular carga simbólica a ponto de serem tidos como indissociáveis dos destinos do Volk alemão e do Peuple francês.

No artigo As leis do crescimento espacial dos Estados, de 1896, Ratzel pronuncia-se da seguinte maneira:

O crescimento do Estado na superfície da Terra pode se comparar ao crescimento em profundidade, que leva a um apego ao solo. É mais que uma metáfora dizer que um povo cria raízes. A nação é uma entidade orgânica que, no curso da história, torna-se cada vez mais apegada à terra onde ela vive. Exatamente como um indivíduo luta contra a terra virgem até transformá-la em campos cultiváveis, uma nação também luta com sua terra, dela se apropriando cada vez mais, com sangue e suor, até que se torna impossível pensá-las separadamente (RATZEL, 1990:183 [1896]).

\footnotetext{
${ }^{5}$ Para o caso francês, vide as pesquisas de Numa Broc, Vincent Berdoulay e Catherine Rhein. Eles destacam os papéis jogados pela guerra franco-prussiana, pelas sociedades de Geografia e pelo colonialismo na institucionalização da Geografia (BROC, 1974, 1977; BERDOULAY, 1995 [1981]; RHEIN, 1982). Para os casos britânico, russo e alemão, ver a consagrada pesquisa de Horacio Capel (1981). A conjuntura histórica e os contextos político, econômico e filosófico que cercaram a Geografia moderna na Alemanha foram bem estudados por Moraes (2002 [1986]), enquanto Franco Farinelli destaca como os pensamentos de Carl Ritter, Alexander von Humboldt e Friedrich Ratzel refletiam mudanças mais amplas da sociedade e do Estado germânicos visando ultrapassar resquícios arcaicos e feudais (FARINELLI, 2000).
} 
No Tableau de la géographie de la France, obra laureada pela intelectualidade de seu país e que o consagrou junto ao público no ano de 1903, Vidal de La Blache anotou coisa semelhante:

Esse solo, tão belo e tão variado, que foi nossa grande força no passado, é rico em ensinamentos. Nele está o princípio dessas restaurações, desses soerguimentos que, certamente, não faltaram em nossa história. Atribuímos a personagens políticos os sucessos e as recuperações por intermédio dos quais nosso país conseguiu se soerguer após derrotas e catástrofes; porém, no fundo, o que representou um trunfo no jogo praticado pelos políticos, o que fez os procedimentos dos homens de Estado se voltarem em benefício do país, foi a benevolência do solo (VIDAL DE LA BLACHE, 2007, p. 344 [1903]).

Entretanto, se uma face da epistemologia geográfica versa sobre o que se pode denominar de enraizamento, a outra aponta para a expansão. Sob argumentos de que índios e negros eram primitivos e não valorizavam a terra, da existência de “vazios demográficos” e do imperativo da ampliação estatal, nada mais legítimo que o mundo como um todo fosse colonizado pela "civilização", senhora da escrita, da matemática, da memória, do direito e do território (ver, por exemplo, SCHMITT, 2014 [1950]). Dessa maneira, estabelecida na própria Europa pelos acordos de Westphalia ${ }^{7}$, porém incapaz de solucionar problemas referentes ao nacionalismo e às identidades linguístico-culturais deste mesmo continente ${ }^{8}$, as incipientes noções de fronteira e de soberania foram impostas a lugares plenos de cultura e de história, mas que, no entanto, careciam ser sintomaticamente identificados como "além-mar", “overseas", "outre-mer" - como se, no fundo, fossem espaços abstratos, terra de ninguém, objetos de um único sujeito.

A confiar na apreciação de Vidal de La Blache, a África era muito instável e dividida tanto em termos sociais quanto geográficos, de modo que era preciso

\footnotetext{
${ }^{6}$ Reclus já havia alertado que "a bela palavra civilização serviu de pretexto para o extermínio mais ou menos rápido de tribos inteiras” (RECLUS, 1861 apud FERRETTI, 2013a, p. 156). Seu “antônimo”, o conceito raça, é primordial no verbete colonisation do Dicionário de Geografia escrito por Albert Demangeon em 1907: "Se definimos a colonização pela ocupação e valorização de um país novo por um grupo já avançado em civilização, tal fenômeno pode ocorrer dentro de um próprio Estado (...). Às vezes o país estava ocupado por uma raça inferior ou simplesmente diferente (...). O uso habitual geralmente reserva o nome de colônia ao território possuído e administrado diretamente (diferente dos protetorados) por uma nação civilizada em um país bárbaro” (DEMANGEON, 1907, p. 193).

${ }^{7}$ Sem desconhecer, porém, as persuasivas críticas ao "mito" westphaliano levantadas por Benno Teschke, para quem Westphalia não inaugurou a era dos Estados Modernos, mas, sim, “codificou as relações geopolíticas da soberania dinástico-patrimonial” (TESCHKE, 2006, p. 55).

${ }^{8}$ Associação explorada com detalhes pelos historiadores Eric Hobsbawm e, principalmente, Benedict Anderson (ANDERSON, 2008 [1983]; HOBSBAWM, 1990).
} 
impor a territorialidade eurocêntrica ao continente, ${ }^{9}$ organizando as fronteiras não segundo padrões locais, mas consoantes aos interesses específicos ditados por ocasião da partilha pelos impérios coloniais $^{10}$. Nesta conjuntura, as cartas geográficas eram preciosas não apenas por serem estratagemas de controle e dominação, mas também - e aqui encaminharemos a questão de modo diferente do habitual - porque tentavam esconder as fragilidades dos conquistadores ${ }^{11}$. As desastrosas conseqüências deste gênero de fronteirização infligido ao continente africano são bastante conhecidas, grafando de modo estrutural a geopolítica da região. Infelizmente, tais desdobramentos ainda permanecem entre nós ${ }^{12}$, servindo

\footnotetext{
${ }^{9}$ Posição adotada em Les confins algéro-marocains (VIDAL DE LA BLACHE, 1911), texto representativo de sua interpretação de fronteira e de território. Coincidentemente, 1911 também é a data de publicação dos dois artigos Les genres de vie dans la géographie humaine (VIDAL DE LA BLACHE, 1911a, 1911b). No entanto, estes últimos tornaram-se bastante conhecidos, ao passo que aquele texto, discutindo o problema da má delimitação fronteiriça entre as colônias francesas da Argélia e do Marrocos, caiu no mais absoluto "esquecimento". Uma breve apresentação de como Vidal de La Blache assimilava a África encontra-se em Ribeiro (2011), enquanto uma investigação mais ampla sobre a representação da África nos Annales de Géographie, periódico no qual os trabalhos acima citados foram publicados, foi feita por Marie-Albane de Suremain (1999).

${ }^{10}$ Sem negligenciar as "múltiplas origens" das fronteiras africanas e suas especificidades, em um processo de longa duração cuja "protogênese" nos remete ao comércio europeu na costa do continente (cf. MBEMBE, 2001, p. 25-29). O historiador Wolfgang Döpcke também reclama uma análise mais complexa sobre as fronteiras da África: além de minimizar os efeitos práticos da Conferência de Berlim, assegura que os africanos já conheciam o conceito de fronteira política antes da colonização europeia e desnuda como os líderes africanos mantiveram o status quo territorial mesmo após a descolonização, com a proposta pan-africanista do ganês Kwame Nkrumah sendo derrotada pela conservadora Organização da Unidade Africana, em 1963. Ele grifa ainda as reivindicações territoriais do Marrocos e o apoio de alguns Estados africanos à França na guerra contra a Argélia (DÖPCKE, 1999). Sua argumentação só reforça a cultura de fronteira aqui desenvolvida.

${ }^{11}$ No entanto, elas também eram motivo de tensão entre as metrópoles. Após conferência em Londres no ano de 1909, na qual as principais potências da época discutiram a confecção da carta internacional do mundo em escala milionésima, Vidal de La Blache, na condição de representante do Ministério da Educação Pública, assume abertamente seus receios nas páginas dos Annales de Géographie: “(...) precauções foram tomadas, como dissemos, para que o modo de transcrição respeitasse, de alguma maneira, a marca de cada metrópole sobre as colônias. No entanto, pela força das circunstâncias, o fato de que regiões que de nós dependem duplamente - pela política e pela ciência - fossem cartografadas sob selo estrangeiro, aos cuidados de outrem, poderia, em certas circunstâncias, causar inconvenientes. É preciso ter em mente que uma obra tão longamente elaborada e já transformada em objeto de emulação internacional será um documento ao qual sua origem e seus progressos não tardarão a conferir um caráter de autoridade quase oficial. Mesmo sendo sobretudo físico, tudo leva a crer que o mapa em questão será invocado nas negociações diplomáticas, nas quais pode ocorrer que um dado lineamento hidrográfico ou orográfico sirva de base para importantes decisões” (VIDAL DE LA BLACHE, 2012, p. 444 [1910]).

${ }^{12} \mathrm{Em}$ uma bela e penetrante meditação, o poeta egípcio-palestino Tamin al-Barghouti, participante ativo da Primavera Árabe, declarou sua total indignação diante das políticas geográficas imperiais do passado e do presente: "Os árabes foram divididos em vinte e dois estados soberanos por potências coloniais, o que garantiu sua dependência econômica e vulnerabilidade militar. As fronteiras foram traçadas em mapas, arames farpados foram estendidos no deserto. Constituíram exércitos, burocracias e forças policiais cuja principal tarefa era proteger o interesse de seus criadores coloniais.
} 
de álibi quer para atitudes xenófobas e políticas anti-imigratórias na Europa, quer para intervenções militares perpetradas pelas antigas metrópoles ${ }^{13}$.

O conjunto de questões exposto até aqui nos leva a perceber algo mais amplo: a Geografia participa ativamente da elaboração do nosso imago mundi, mas como mito - o mito do espaço moderno. Não se trata apenas do Estado Nacional Territorial, mas de algo muito além dele. Criou-se uma cultura da fronteira no mundo ocidental, cultura esta que forjou o espaço como separação e não como integração - do Lebensraum ao Tratado de Versalhes, do Muro de Berlim aos condomínios fechados tentando blindar os mais ricos dos dissabores do contato com o "outro". A representação mais consagrada do mito do espaço moderno, os mapas, não contém senão ilusões de fronteira, limites revestidos pelo rigor e pela exatidão matemático-astronômica, porém altamente ideológicos e mistificadores ${ }^{14}$.

Reconhecer tal quadro nos permite visualizar com mais clareza os caminhos e os descaminhos assumidos pelo pensamento geográfico. Não é difícil sustentar que parte não negligenciável desta história tem sido majoritariamente narrada à luz da separação entre ciência e política ou, quando esse não é o caso, é visível o descuido em relação aos fundamentos políticos da disciplina ${ }^{15}$. Assim, torna-se mais plausível entender tanto a operação de “amnésia” diante da obra de Élisée Reclus, quanto as inúmeras repreensões endereçadas a Ratzel. O motivo é praticamente o mesmo: ambos não dissociavam a Geografia da política e explicitavam esta postura como algo que, do ponto de vista da epistemologia moderna, afastava o pensamento da cientificidade.

Porém, basta olhar com mais atenção para o século XIX para constatar que tais personagens possuíam enorme relevo: um dos fundadores do movimento

No entanto, o colonialismo não conseguiu convencer a maioria dos árabes de suas novas identidades. Ele dividiu a terra, mas não a linguagem; confinou as pessoas, mas não a sua imaginação. Portanto, hoje a mera existência de uma poesia árabe é um ato de resistência. Ela zomba das fronteiras, dos governos e dos ditames da ordem internacional colonial e neocolonial” (ALBARGHOUTI, 2013, p. 5, grifo nosso).

${ }^{13}$ Uma arguta problematização da geopolítica atual e sua estreita associação com o colonialismo residem nos argumentos de Tzvetan Todorov (TODOROV, 2010 [2008]; 2012).

${ }^{14}$ Ver os aportes de Cássio Eduardo Viana Hissa e de Boaventura de Sousa Santos a respeito (HISSA, 2002; SANTOS, 2010).

${ }^{15}$ Um dos casos mais notórios diz respeito a Paul Vidal de La Blache, que passou quase todo o século XX rotulado como apolítico - a despeito de boa parte de sua produção evidenciar absolutamente o contrário. Mesmo em um texto como o de Pascal Clerc, cujo objeto é exatamente mostrar como a ideologia colonial impregnou os geógrafos franceses, pode-se ler que "Vidal de La Blache, o primeiro chef de file da Geografia francesa, quase não escreveu sobre as questões coloniais" (2011). Outros querem encontrar em Vidal de La Blache, comparado a Ratzel, claro, uma "geopolítica alternativa”, repetindo uma dicotomia que não faz sentido algum (PARKER, 2000). Uma amostra do pensamento político de Vidal de La Blache pode ser encontrada diretamente em seus próprios textos, traduzidos na seção terceira do livro Vidal, Vidais: textos de geografia humana, regional e política (HAESBAERT; PEREIRA; RIBEIRO, 2012), bem como nas apreciações de Ribeiro (2010; 2010a). 
anarquista internacional ao lado do geógrafo russo Piotr Kropotkin ${ }^{16}$, Reclus contrapõe-se com veemência ao colonialismo, ao racismo, à escravidão e às interpretações eurocêntricas sobre povos e culturas afro-asiáticas. Sua Geografia é instrumento político essencial na divulgação dos ideais libertários. Sua interpretação do processo histórico é uma declaração aberta em nome do humanismo e da fraternidade universal (RECLUS, 1883; 1894; 1908; 1985 [s/d]; 1985 [s/d a]). Posição distinta assumirá Ratzel, para quem a história é uma luta estratégica por espaço. Influenciado por Malthus, Hegel, Darwin e Ritter, sua Geografia dedica-se a apreender o Estado e seu desenvolvimento político, o papel das fronteiras, a relação do povo e da nação com o solo, as expansões territoriais (RATZEL, 1897; 1898; 1898a; 1900).

Por outro lado, a "Escola" ${ }^{17}$ Francesa de Geografia tentará afastar-se da Geopolitik alemã cultivando o ramo Géographie Politique ${ }^{18}$ (DEMANGEON, 1932; 1939). Manobra ideológica possibilitada pela linguagem, bem o sabemos ${ }^{19}$,

\footnotetext{
${ }^{16}$ Vide as posições progressistas de Kropotkin em seu célebre artigo $O$ que a geografia deve ser, de 1885. Chamam atenção suas críticas à Geografia ensinada nas escolas: instrumento do nacionalismo e do colonialismo, “é preciso modificá-la amplamente” (1986 [1885]). Admirável também é sua denúncia da associação entre Estados europeus e capitais privados na corrida por territórios que provocaria a Primeira Guerra Mundial (KROPOTKIN, 2014 [1913]).

${ }^{17}$ Termo cada vez menos apropriado para lidar com a notória diferenciação que caracteriza os vários membros deste grupo, como bem percebeu Paul Claval (1998, p. 119-152).

${ }^{18}$ Embora Demangeon tenha insistido na distinção entre Géographie Politique e Geopolitik, o subtítulo de seu livro de 1923 acaba por trair suas intenções: L'Empire britannique. Étude de géographie coloniale. Um panorama desta obra e de seu contexto foi feito por Claval, que destaca seu caráter avant-garde ao apresentar a Geografia colonial como ciência social (1994). Entretanto, é impossível não constatar o intenso teor racista e determinista desta obra, na qual o autor se opõe à mistura racial e à efetiva colonização branca nos trópicos por causa do forte calor (DEMANGEON, 1923; 1940).

${ }^{19}$ Por esse motivo, parece-nos difícil sustentar as posições de Claude Raffestin, Dario Lopreno e Yvan Pasteur, para quem só existe geopolítica a partir da aparição do termo, cunhado pelo sueco Rudolf Kjellén, em 1916, no livro Der Staat als Lebensform (O Estado como forma de vida). Assim sendo, Mahan, Mackinder e Ratzel não podem ser considerados geopolíticos (RAFFESTIN; LOPRENO; PASTEUR, 1995, p. 23 e 80). Mais sensata é a abordagem de Michael Heffernan: uma vez que as relações entre Geografia e poder já existiam sob o rótulo geografia política, a emergência do termo Geopolitik (localizada por ele em 1899, tendo como parâmetro o próprio Kjellén) é uma questão de terminologia. Aliás, sua interpretação sobre o surgimento da geopolítica é muito original: mais que simbolizar a glória dos Impérios europeus, a geopolítica representa o sentimento de uma ampla mudança na ordem mundial, definida pelo declínio da Europa no início do século XX e pela progressiva força internacional dos Estados Unidos da América (HEFFERNAN, 2000). Em se tratando do nacionalista Kjellén, cujos principais textos foram escritos em sueco e em alemão (editados neste idioma por Karl Haushofer, destaque-se), dois de seus artigos jornalísticos estão disponíveis em inglês e abordam temas geopolíticos de extremo interesse na década de 1920: a internacionalização da política interrompida pela I Guerra Mundial e o papel da Liga das Nações neste processo, bem como a relação dos Estados Unidos com os demais países do continente americano. Neste último, ele cita o Brasil (KJELLÉN, 1920; 1921). Uma bela síntese de seu pensamento foi esboçada por Sven Holdar (1992).
} 
uma vez que Paul Vidal de La Blache, Albert Demangeon, Emmanuel de Martonne, Lucien Gallois, Jean Brunhes e Emmanuel de Margerie - para não citar Marcel Dubois, fundador dos Annales de Géographie ao lado de Vidal, em 1891, e primeiro ocupante da cadeira de géographie coloniale na Sorbonne, em $1893^{20}$ - não só eram partidários do colonialismo ${ }^{21}$ como emprestaram sua expertise ao governo francês no escrutínio e na reorganização das fronteiras territoriais durante e após a Primeira Guerra Mundial (vide WOLFF, 2005). Ou seja: em um período de extrema competição entre "Repúblicas Imperiais" ${ }^{22} \mathrm{em}$ pleno esforço de industrialização (e, portanto, ávidas pelo controle dos recursos naturais), os geógrafos franceses não fizeram nada de diferente em relação aos seus pares alemães. Entretanto, reproduziu-se mundo afora uma versão totalmente despropositada: Vidal de La Blache foi rotulado como "possibilista”, expressão nunca utilizada por ele (falecido em 1918, logo, antes da ficção febvreana de 1922) e, que, o reduzia a uma "geografia humana modesta" ${ }^{23}$, e sua referida "Escola" foi

\footnotetext{
${ }^{20}$ Talvez a muitos surpreenda a aula inaugural do curso de Geografia colonial de Marcel Dubois, pois suas observações sobre teoria e método geográficos estão longe de serem ingênuas. Tendo Ritter como referência, Dubois sugere que a Geografia seja uma filosofia das ciências; preocupa-se com que seu papel vá além da descrição pela descrição, do ato de decorar fatos e de servir como introdução à história; e explora a necessidade de articular diferentes espaços para a compreensão do todo. O desenvolvimento do instrumental epistemológico da Geografia aspirava a gestão científica do meio ambiente a fim de otimizá-lo. Na Geografia colonial, tudo girava em torno da exploração racional da natureza, sendo ela própria “uma modalidade da ciência econômica” (DUBOIS, 1893, p. 130).

${ }^{21}$ De acordo com Emmanuelle Sibeud, “os geógrafos reagrupados em torno dos Annales de géographie procuram e encontram aliados no seio do pessoal colonial” (SIBEAUD, 2008, p. 89). Embora discordemos de vários de seus argumentos, uma interpretação dos Annales como uma revista divulgadora do colonialismo foi realizada por Olivier Soubeyran e por Cristina D'Alessandro (SOUBEYRAN, 1997; D’ALESSANDRO, 2003). Já Marie-Claire Robic contextualiza pormenorizadamente a gênese do referido periódico, grifando as disputas institucionais no interior do campo geográfico e a novidade representada pelo termo géographie humaine (1993).

${ }^{22}$ Com esse termo, fazemos coro à tese de Craig Calhoun de que é um erro opor nação e império como se ambos fossem incompatíveis. Segundo ele, “o equívoco mais grave consistiu no endosso de duzentos anos de discurso europeu no qual as discussões sobre cidadania e identidade nacional foram formuladas através de um contraste com os impérios nefastos de terceiros, sem que houvesse grande perturbação no fato de os Estados Nacionais emergentes serem eles próprios potências imperiais” (CALHOUN, 2008, p. 45).

${ }^{23}$ Pronúncia literal de Febvre na obra mencionada (FEBVRE, 1991, p. 68 [1922]). Entretanto, sua tentativa de dissociar a Geografia da política mostrou-se incapaz de esconder seu enorme interesse por este tema, tal como atestam seus ricos artigos sobre cartografia e fronteira (FEBVRE, 1962 [1936]; 1962 [1934-1936]; 1962 [1934]; 1962 [1929]; 1962 [1928]; 1962 [1908]). Ao analisar a origem e as transformações da palavra frontière, ele desnuda toda sua visão de mundo: "Geógrafos normalmente aplicam-se a pesquisar, no solo, traços de antigas zonas de isolamento, seja onde elas são apenas lembranças, como na França, seja onde elas permanecem como a viva realidade. É o caso do centro da África, onde o homem normalmente instala-se 'na clareira' na vasta extensão impenetrável da floresta. Trata-se de Estados pouco importantes. Fronteiras de outro tipo aparecem quando Estados mais amplos e mais complexos são criados e entram em contato com povos refratários à ordem, à paz, à civilização material ou moral que tais Estados representam" (FEBVRE,
} 
rotulada como empirista no campo epistemológico e ingênua no terreno político: eis as más heranças forjadas nos anos vinte pelo historiador Lucien Febvre em $A$ terra e a evolução humana: introdução geográfica à história; e atualizadas nos anos de 1970 pelo geógrafo Yves Lacoste em A geografia - isso serve, em primeiro lugar, para fazer a guerra ${ }^{24}$ (FEBVRE, 1991 [1922]; LACOSTE, 1988 [1976]). A nosso ver, a consagração de ambos diz muito sobre a história do pensamento geográfico no transcorrer do século XX: excessivamente factual e descritiva, limitando-se a contar a trajetória dos grandes geógrafos e a "evolução" de suas ideias (cf. contestam também SMITH; GODLEWSKA, 1994).

Terão os geógrafos receio de assumir que sua trajetória foi forjada na esfera da política operada pelo status quo? É um pouco nesse sentido que Edward Soja assinala, em uma espécie de pedido de desculpas, o quanto o determinismo e a geopolítica macularam o status da Geografia no âmbito das Ciências Humanas (SOJA, 1993 [1989]). Talvez seja preciso ampliar nossa perspectiva. Quanto ao determinismo, Soja parece esquecer que a tradição intelectual de interpretar a sociedade a partir da natureza vai muito além da Geografia, tendo raízes na Grécia Antiga até chegar ao Iluminismo e depois ao cientificismo do século XIX. No tocante à geopolítica, uma vez que a origem das modernas Ciências Humanas localiza-se na progressiva consolidação dos Estados Nacionais e na expansão do capitalismo (ver CASTRO-GÓMEZ, 2005 [2000]), basta verificarmos o forte traço conservador presente na Sociologia de Max Weber e de Émile Durkheim, na História de Ernst Lavisse e Lucien Febvre e na Antropologia de matriz evolucionista.Claro está que o conceito de espaço vital (Lebensraum) proveniente de Ratzel, em 1897; retomado pelo geógrafo e general Karl Haushofer (cofundador da Zeitschrift für Geopolitik, em 1924) e citado à revelia por Adolf Hitler em Mein Kampf(1927) para fins nazistas ${ }^{25}$, não enobrece nenhuma ciência. No

1962, p. 15-16 [1908]). Para uma crítica à interlocução de Febvre com a Geografia, ver Ribeiro (2009).

${ }^{24}$ Não se pretende desmerecer o livro de Lacoste, cuja relevância política é notável, mas tão somente grifar sua leitura errônea e restrita da obra de Vidal de La Blache e da Escola Francesa. Para uma ampla e equilibrada apreciação dos impactos de Lacoste e do periódico por ele criado, ver Claval (2000).

${ }^{25}$ Entre outros aspectos, a pesquisa de Ian Kershaw sobre Hitler é bastante instrutiva ao registrar a proeminência do Lebensraum na conformação da ideologia nacional-socialista e do pangermanismo, como no trecho: "Hitler dificilmente deixou de ler os escritos imperialistas e geopolíticos em circulação sobre 'espaço vital'. Entre eles, parece altamente provável que as obras de Karl Haushofer, o maior expoente da 'geopolítica', tenham sido uma fonte significativa para sua noção de Lebensraum, lidas em primeira mão ou de forma resumida. Por intermédio de Rudolf Hess, Hitler já conhecia Haushofer antes de 1922. A influência desse autor foi provavelmente maior do que esse então professor de Munique se dispôs a reconhecer mais tarde. Se não conhecia suas obras antes, é certo que Hitler teve tempo de lê-las na prisão, bem como as de Friedrich Ratzel, o outro teórico importante da geopolítica. Claro que não podemos provar que as leu de fato, mas parece, no mínimo, que tomou conhecimento das linhas gerais dos argumentos deles por intermédio de um ex-aluno de Hess que fora aluno de Haushofer” (KERSHAW, 2010, p.187 [2008]). A presença do argumento 
entanto, apenas para mencionar um exemplo célebre, acaso a Filosofia abrirá mão de Martin Heidegger por conta de suas ligações com o III Reich? ${ }^{26}$

Enfim, não se trata, evidentemente, de reabilitar a geopolítica em seu sentido clássico (estatal, belicoso e excludente), mas de reconhecer que a Geografia é, necessariamente, geo-política, entendida aqui como o artifício de recortar, classificar, mapear, criar e extinguir espaços, regiões, territórios, lugares. Tal condição fez da Geografia um dos discursos instituintes da modernidade e é justamente em virtude disso que ela situa-se no âmago de um dos movimentos de vanguarda nas Ciências Humanas das últimas quatro décadas: o pós-colonialismo.

\section{Pós-colonialismo: contribuições e desafios à Geografia}

No esforço de interrogar a epistemologia moderna e as narrativas que a sustentaram, tudo nos leva a crer que intelectuais como Edward Said, Boaventura de Sousa Santos, Nelson Maldonado-Torres, Dipesh Chakrabarty, Ramón Grosfoguel e Walter Mignolo têm, sem que eles tenham clara consciência disto, questionado os próprios fundamentos da Geografia (SAID, 2007 [1978]; SANTOS, 2010; MALDONADO-TORRES, 2010 [2004]; CHAKRABARTY, 2008 [2000]; GROSFOGUEL, 2010 [2008]; MIGNOLO, 2003 [2000]; 2009). Não é mera coincidência, portanto, o uso dos termos fronteira, território, geopolítica, lugar, escala, pois o pensamento pós-colonial (ou seria descolonial?) mobiliza a Geografia como um todo, acionando-a em diversas ocasiões (ver CRUSH, 1994; RYAN, 1994; CLAYTON, 2008). O que nos mostra a emblemática passagem de Edward Said, em Cultura e Imperialismo:

geográfico concernente ao poder do espaço é mais que evidente em Mein Kampf (HITLER, 1998 [1927]). No que diz respeito à interpretação de Kershaw, ainda que não deixe de mostrar os laços e as posições institucionais assumidas por Haushofer durante e em nome do regime nazista (1933-1944), o geógrafo alemão Henning Heske sugere que sua influência foi muito maior na difusão das ideias geopolíticas na Alemanha que sobre a geopolítica efetivamente posta em prática pelo nacionalsocialismo. No testemunho dado à Nuremberg War Crimes Investigation (ele consegue escapar do Tribunal de Nürenberg), embora tenha feito questão de afastar-se das ideias contidas em Mein Kampf - destacando inclusive sua prisão no campo de concentração em Dachau (1998 [1945]) -, Haushofer e sua esposa acabaram por cometer suicídio no ano de 1946 (HESKE, 1987). Parte de suas ideias foram resumidas no programático Why Geopolitik?, no qual cita Ratzel, Kjellen e Mackinder, enfatiza a centralidade do solo e assevera que a geopolítica "veio para ficar" (HAUSHOFER, 1998 [1925]). Para uma análise de como os principais periódicos alemães de Geografia foram afetados após a ascensão do nazismo, consulte Heske (1986).

${ }^{26}$ Vide a entrevista concedida por Heidegger ao semanário Der Spiegel no qual, entre outros temas, trata da sua versão para o episódio em que foi nomeado reitor da universidade de Freiburg durante o nazismo (HEIDEGGER, 1976 [1966]). Nos termos de Nelson Maldonado-Torres, “A geopolítica de Heidegger é, como refere Bambach, uma política baseada na relação íntima entre o povo, a sua língua e a sua terra. A geopolítica é, simultaneamente, uma política da terra e uma política de exclusão” (MALDONADO-TORRES, 2010, p. 402 [2004]). 
Para os objetivos deste livro, concentrei-me nas disputas efetivas pelas terras e pelos povos dessas terras. O que tentei fazer foi uma espécie de exame geográfico da experiência histórica, tendo em mente a ideia de que a terra é, de fato, um único e mesmo mundo, onde praticamente não existem espaços vazios e inabitados. Assim como nenhum de nós está fora ou além da geografia, da mesma forma nenhum de nós está totalmente ausente da luta pela geografia. Essa luta é complexa $e$ interessante porque não se restringe a soldados e canhões, abrangendo também ideias, formas, imagens e representações (SAID, 1995, p. 37-38 [1993], grifo nosso).

Gostaríamos de reforçar que a argumentação pós-colonial enfatiza a dimensão geográfica da produção de conhecimento. Assim, a modernidade e sua ambição universalizante passam a ser vistas como o plano de uma província do mundo e não do mundo todo. O eurocentrismo e seus mandatários são duramente criticados, já que exportaram valores particulares como se fossem globais e, com isso, depreciaram culturas, povos, técnicas, línguas e civilizações rotulando-as como mitos, lendas, folclores e dialetos. Uma gama de pessoas, culturas e falas foram deslegitimadas apenas pelo fato de estarem localizadas em espaços tornados colônias. É o centro que diz quem é a periferia; a identidade que afirma a presença da alteridade; o "Velho Mundo" que arquiteta o "Novo Mundo". Há, portanto, uma face propriamente geográfica no processo de consolidação da Europa como o lócus epistêmico mais capaz e mais autorizado a proferir verdades e a conceber soluções para o mundo. Porém, essa mesma face também abre caminho para o interpelamento de tal situação, num enfoque valorizador da escala e do sujeito locais no seio do projeto político de subversão da categorização espacial que ainda rege a construção do conhecimento (vide CHAKRABARTY, 2008 [2000]). Este movimento deve vir acompanhado por uma atitude que "questione o lugar do investigador” (SPIVAK, 2010, p. 19 [1985], grifo nosso).

Nessa trilha, o pensador argentino Walter Mignolo assume destaque com as noções de geopolítica do conhecimento e epistemologia territorial, ressaltando que todo e qualquer discurso possui um enraizamento - inclusive o dos pós-coloniais (MIGNOLO, 2008) - e que este é fundamental na compreensão da história do mundo elaborada pelas Ciências Humanas. Todo universal é, inequivocamente, local, e o entendimento amplo desta equação aponta rumo a uma desierarquização dos saberes (MIGNOLO, 2003 [2000]). Tal qual Mahatma Gandhi e Martin Luther King pregaram a desobediência civil, Mignolo recomenda a "desobediência epistemológica” frente aos cânones científicos europeu e anglo-saxão (MIGNOLO, p.15). Em se tratando de uma abordagem acentuadamente geográfica e contestadora, não é de surpreender que a noção de fronteira venha a emergir no 
centro do pós-colonialismo. Também dialogando com Mignolo, Grosfoguel registra a expressão pensamento crítico de fronteira ${ }^{27}$ e define-a como:

a resposta epistêmica do subalterno ao projeto eurocêntrico da modernidade. Ao invés de rejeitarem a modernidade para se recolherem num absolutismo fundamentalista, as epistemologias de fronteira subsumem/redefinem a retórica emancipatória da modernidade a partir das cosmologias e epistemologias do subalterno, localizadas no lado oprimido e explorado da diferença colonial, rumo a uma luta de libertação descolonial em prol de um mundo capaz de superar a modernidade eurocentrada. Aquilo que o pensamento de fronteira produz é uma redefinição/subsunção da cidadania e da democracia, dos direitos humanos, da humanidade e das relações econômicas para lá das definições impostas pela modernidade europeia. O pensamento de fronteira não é um fundamentalismo antimoderno. É uma resposta transmoderna descolonial do subalterno perante a modernidade eurocêntrica (GROSFOGUEL, 2010, p. 480-481).

Ao que acresceríamos: juntamente com a cidadania, a democracia e os direitos humanos, o pensamento de fronteira também precisa rediscutir o espaço, a região, o território, o lugar, a paisagem, a rede, isto é, as maneiras pelas quais captamos a geograficidade da vida social. Parte considerável da Geografia tem se dedicado a mimetizar paisagens, recortes regionais, territórios. Porém, no instante em que os geógrafos privilegiam a distribuição dos homens e dos fenômenos sem indagar os fundamentos políticos da matriz espacial, eles acabam por legitimar os limites do mundo. Ou, dito de outra forma, eles corroboram o mundo como limite e não como fronteira. No primeiro caso, o mundo é apresentado enquanto "realidade objetiva", estrutura incontornável a cercear alternativas de reflexão e de ação, já no segundo ele é vislumbrado como um conjunto de possibilidades pluritópicas $e$ pluriutópicas. Ou seja, mimetizar o mundo é aderir às estruturas hegemônicas de poder; "fronteirizá-lo" quer dizer afrontá-lo, interrogar por dentro seus territórios. Eis outra conotação para fronteira, portanto. Assim, recordemos a lição do filósofo Walter Benjamin: a história não pode ser uma representação historicista do passado, mas, sim, instrumento de reabilitação do mesmo. Incorporado à

\footnotetext{
${ }^{27}$ Desafortunadamente, a excelente tradução brasileira do livro Histórias locais/projetos globais: colonialidade, saberes subalternos e pensamento liminar, de Walter Mignolo, optou por verter border thinking como "pensamento liminar" quando, considerando o peso geográfico na análise póscolonial, mais adequado seria pensamento fronteiriço ou de fronteira. Assim procedeu a versão brasileira de Epistemologias do Sul, ótima coletânea organizada por Boaventura de Sousa Santos e Maria Paula Meneses (SANTOS; MENESES, 2010), no artigo assinado por Grosfoguel adequadamente intitulado Para descolonizar os estudos de economia política e os estudos póscoloniais: transmodernidade, pensamento de fronteira e colonialidade global (GROSFOGUEL, 2010).
} 
Geografia, tal ensinamento pode ser assim traduzido: espaço, região e território não devem ser naturalizados ou cristalizados. A Geografia e as representações por ela engendradas ${ }^{28}$ carecem ser “escovadas a contrapelo" (BENJAMIN, 2005 [1940], p. 70).

Outro exemplo a nos auxiliar nessa tarefa é o de que, em meio aos horrores da Segunda Guerra Mundial (e apenas três anos após a publicação de Benjamin acima citada), o artista catalão Salvador Dalí alcançou com profundidade a relação entre espaço e política. O resultado é a tela Criança geopolítica observando o nascimento do novo homem (1943), cujo impacto permanece bastante atual - e ainda está por ser decodificado pelos geógrafos. Sem negligenciar determinadas orientações políticas conservadoras assumidas por Dalí, algumas de suas pinturas e esculturas encarnam vigorosa crítica ao espaço e ao tempo na modernidade. Ao distorcê-los, ele nos estimula a imaginá-los de outra forma. Raciocinar assim nos leva a repensar os modos pelos quais a Geografia e o seu passado vêm sendo idealizados, bem como o papel da epistemologia no entendimento da natureza da Geografia.

Referimo-nos às críticas levantadas pelo historiador François Dosse a um suposto atraso epistemológico por parte da Geografia (DOSSE, 2007 [1992]), discurso este reproduzido também por Milton Santos desde Por uma geografia nova até $A$ natureza do espaço, no qual defende que a Geografia carece de objeto preciso, conceitos claros e uma teoria sólida (SANTOS, 1978; 1996). Convém indagar se tais autores não trabalham com uma concepção racionalista e cientificista de epistemologia, bem como se suas ponderações não estariam restritas ao debate "entre correntes" que, a nosso ver, "fetichizou” a Geografia durante todo o século XX. Sim, pois apenas isso pode justificar a posição de ambos. Afinal, como defender uma possível fragilidade epistemológica da Geografia se ela foi um dos elementos nucleares na instituição política e discursiva da modernidade? Como vimos sustentando até então, a Geografia elaborou a imagem que temos do mundo; ela direcionou nosso raciocínio espacial. Como se não bastasse, também ajudou a moldar nosso léxico conceitual, formado por termos como conquista, anexação, violência, expropriação, controle, raça, racismo, meio, organismo, evolução, adaptação, inferioridade, superioridade, civilização, barbárie, povo, nação, nacionalismo, Estado, desenvolvimento, progresso, periferia, Terceiro Mundo. Embora não possamos nos deixar aprisionar por tal quadro, é tamanha a força desta epistemologia que temos enormes dificuldades de pensar fora dela. Aqui, utilizamos a palavra epistemologia deliberadamente a fim de refutarmos a ideia de que ela representa a coerência teórico-metodológica que caracteriza um campo científico, versando acerca da

\footnotetext{
${ }^{28}$ Para uma interessante contraposição à forma como a Geografia e o pensamento moderno tecem suas representações por e a partir de fronteiras, consulte a reflexão da geógrafa alemã Dagmar Reichert (1992).
} 
inteligibilidade de seus conceitos e categorias. Tal noção integra um olhar formalista da epistemologia, cujo desdobramento mais pernicioso, porém nem sempre tão visível, reside no silenciamento da ciência como política (vide FOUCAULT, 2004 [1971]).

Para além das estéreis polêmicas cultivadas pelos geógrafos sobre qual seria seu principal objeto de estudos ou a definição mais válida de região, precisamos apreender a Geografia como uma estrutura de pensamento geradora de determinadas ações, uma Weltanschauung. Portanto, o que não lhe falta é epistemologia, muito pelo contrário! É necessário, sim, reposicioná-la, descolonizá-la, "mudar a geografia da razão" (MIGNOLO, 2009, p. 14; 2003, p. 261-262 [2000]). Tal enfoque obriga-nos a ver e a conjecturar sob novos ângulos. $\mathrm{E}$ destes emergirão imagens, enredos e personagens que, antes de serem reproduções de um mundo pronto e acabado, são versões. Logo, categorias e métodos serão subvertidos, e não apresentados mimeticamente. Estamos diante de outra concepção de epistême, ${ }^{29}$ de outra estética. E, como não poderia deixar de ser, inverte-se também a tradicional acepção de fronteira, que adquire o sentido de espaço aberto, fricção positiva geradora de conhecimento horizontal, lócus de implementação da transdisciplinaridade, intercâmbio de gentes e de falas, território de aceitação da diferença. Enfim, o mesmo conceito que outrora fomentou o mundo-como-fragmentação passa a ser a pedra de toque no delineamento de uma alternativa à Geografia instituída pela tradição imperial.

Se quisermos levar adiante tal empreitada, precisaremos admitir que a Geografia tem atuado na condição de taxonomia do mundo. Com suas cartas, geógrafos têm hierarquizado pessoas e lugares, línguas e culturas. Mapas são arranjos, nomenclaturas, coordenadas; não são entes autônomos, não podem ser lidos somente como instrumentos técnicos de navegação e de posição, pois, uma vez apartados de seus elementos histórico-sociais, os efeitos do poder e da política podem ser facilmente eclipsados. Mapas fazem parte de um gênero de percepção espacial responsável por orientar nossa maneira de discernir fenômenos. A disposição dos continentes ao redor do globo terrestre é uma sutil, porém pujante, classificação espacial. Cartas são formas de conceber o mundo e nenhuma representação é isenta de valores. A incorporação da América e da Oceania não se impôs como essencial na preparação da imagem moderna de mundo? De Ortelius a Mercator, isto é, do antigo Teatro do Mundo - cujos mapas vinham acompanhados de outras representações pictóricas - ao moderno Atlas - pleno de racionalidade e produzido para fins comerciais (sem esquecer do planisfério de Waldseemüller, em

\footnotetext{
${ }^{29}$ Eis um dos grandes desafios para o pós-colonialismo, pois, conforme registrou audaciosamente o português João Arriscado Nunes, “se a epistemologia é um projeto hegemônico, de imposição de uma soberania epistêmica, indissociável da ciência moderna, como entender um projeto alternativo que retoma a própria ideia de epistemologia para caracterizar de maneira positiva a diversidade das formas de conhecimento existentes no mundo e as condições de sua validade?” (NUNES, 2010:281).
} 
1507, onde consta a primeira aparição do termo América), a grade de localização foi sensivelmente alterada de modo a fazer da Europa (termo pouquíssimo usado na Idade Média, diga-se) o centro do mundo e, dos demais espaços, sua periferia (BESSE, 2003, 2005; DUSSEL, 2005 [2000]).Certamente, localizar está longe de ser apenas algo físico, objetivo, mas uma perspectiva, uma projeção de valores e de signos. Num processo de longa duração, coube à Geografia recolher e costurar o imaginário acerca do mundo e de seus espaços por meio de uma narrativa pictórica universal, travestindo sua intervenção política sob rótulos como "geografia das civilizações”, "sociedade e natureza”, ou mesmo romanceando a formação dos Estados Nacionais. Igualmente, a noção de posição geográfica foi usada como álibi para fins de expansionismo territorial.

Enfim, a cartografia tornou-se célebre como ato de localizar, mas tal ato nem sempre foi percebido como uma poderosa ferramenta de classificação. Por este motivo, o pós-colonialismo demanda outra cartografia (LANDER, 2005 [2000]). No mesmo sentido, hoje são discutidas novas cartografias sociais, etnocartografias, utilização de geotecnologias gratuitas e livres, tal como no Projeto Nova Cartografia Social da Amazônia (ver www.novacartografiasocial.com/index.php). Até que ponto estamos dispostos a reconhecer isso e, principalmente, a arcar com todos as suas implicações?

\section{História do pensamento geográfico: reunindo elementos para a crítica}

Para tanto, é imprescindível pensar a Geografia em termos processuais, históricos, em íntima associação com o desenvolvimento da modernidade. A nosso ver, a partir da segunda metade do século XX a Geografia transformou-se em uma ciência excessivamente presentista, apartada de explicações capazes de discorrer sobre a pluralidade do tempo e as estruturas mais amplas da vida social. Perdemos de vista os arquivos, a interlocução com os historiadores. Afastamo-nos de temas globais como expansão ultramarina, escravidão, colonialismo, formação territorial. Isso resultou em um empobrecimento do método geográfico, que passou a descuidar da história como um todo e a mirar apenas o agora, o atual — denotando, assim, uma leitura pueril do processo histórico exclusivamente como mudança e progresso - sem levar em conta as permanências de longa duração, as camadas da história, as escalas temporais. Dissociado da história, ocorre uma espécie de naturalização do espaço, das fronteiras. Christian Grataloup não escreve L'invention des continents. Comment l'Europe a découpé le monde tentando desmistificar tal impressão? Benno Werlen não investe contra uma Geografia excessivamente espacial que acabou por descuidar das ações humanas? Fernand Braudel não aconselhou os geógrafos a estudarem mais o "verdadeiro ambiente do 
homem”, a sociedade? (GRATALOUP, 2009; WERLEN, 1993; 2000; 2012; BRAUDEL, 1997, p. 78 [1941-1944]).

Eis a relevância da interação com o processo histórico, que precisa ser assimilado como fundamento geral e incontornável de toda e qualquer Geografia. Ele permite que os geógrafos não abandonem os sujeitos, os eventos ou as estruturas da história, alertando para o fato de que a espacialidade e, claro, suas representações, são produtos sociais e não aspectos externos à mesma ou alheios à dinâmica histórica. O distanciamento em relação à historicidade incide, inclusive, no tratamento que a Geografia empresta aos seus conceitos e ao próprio pensamento geográfico. Não raro, ambos são apresentados em simplificadas sequências cronológicas, linhas abstratas de tempo desprovidas de qualquer contexto ou problematização social, como se nossas controvérsias epistemológicas não fossem tensões político-ideológicas ao redor da sociedade, da cultura, da economia. Não sem pesar, interrogamos: o que tem sido a história do pensamento geográfico senão a história das Geografias e das idéias encerradas apologeticamente em torno dos Estados-Nação? Daí a insistência na fórmula "Escolas Nacionais de Geografia”, cuja razão de ser empobrece a temporalidade e a espacialidade da sociedade ao consagrar as teleologias do progresso e do desenvolvimento (ver BHABHA, 2010 [1990]). Graças a este cenário, é sintomático notar que uma interessantíssima história (ou será contra-história?) da Geografia está sendo esboçada justamente por não geógrafos. Referimo-nos, claro, ao pós-colonialismo.

A história da Geografia carece ser reexaminada ${ }^{30}$, pois a trama consagrada até então tem se limitado a ser a história das idéias geográficas, de conceitos gerados tão somente no plano do racionalismo. A trajetória da Geografia pouco tem sido contada sob a égide das disputas territoriais e suas implicações. É forçoso concebêla não em termos de sucessão de paradigmas, mas como campo privilegiado para o entendimento das formas pelas quais as sociedades desenvolveram seu modus operandi espacial, extraindo tanto as visões de mundo que engendraram tal configuração quanto os embates dela resultantes. O fato é que a Geografia tem sido cúmplice de uma epistemologia unívoca e redutora da diversidade do mundo. Neste teatro, o papel da história da Geografia é o de narrar as linhas-mestras dessa operação, canonizando geógrafos, fixando correntes e identificando conflitos meramente superficiais. Alterar esta conjuntura quer dizer frisar a constituição político-discursiva dos conceitos e da história da Geografia, e não contentar-se com um enfoque contemplativo dos mesmos (ver GODLEWSKA, 1989; 1999; LIVINGSTONE, 1992; DRIVER, 1992; ESCOLAR, 1993; 1998; ARRAULT, 2007; DEPREST, 2009; RIBEIRO, 2009, 2012a; FERRETTI, 2011, 2013).

\footnotetext{
${ }^{30}$ A própria fórmula "história do pensamento geográfico" parece repleta de imprecisão, repelindo as práticas e as ações dos sujeitos.
} 
Partimos do princípio de que a história do pensamento geográfico é uma poderosa janela interpretativa através da qual podemos apreender as motivações e os interesses que impeliram as sociedades rumo à confecção de cartas, levantamentos topográficos, mapeamento de recursos, tratados fronteiriços, divisões administrativas, registros paisagísticos, delimitações regionais. Ela é um modo particular de inquirir agentes, instituições e sociedades a respeito das razões que os levaram a erigir e a difundir a Geografia tal como a conhecemos. Dada a consciência de que a maior parte dos saberes geográficos disseminados até então foram, efetivamente, concebidos em nome do status quo, tal estado de coisas alimenta o desejo de reinventar a Geografia e suas categorias (HARVEY, 2000; SANTOS, 2002; FERREIRA, 2009; PORTO-GONÇALVES, 2010), permitindo também escavar as Geografias alternativas historicamente subjugadas.

Portanto, interpelar as narrativas que moldaram a história do pensamento geográfico é uma forma de ler o inusual, reverter a apropriação tradicional dos discursos, destituir imagens estereotipadas. Do contrário, dificilmente poderemos atingir outras práticas geográficas ${ }^{31}$, pois estas carecem de outro espaço de representação - situado para além dos discursos convencionais estabelecidos ${ }^{32}$.

Outro benefício depreendido do investimento na história do pensamento geográfico: ele nos lança rumo a outros ângulos do próprio processo histórico, ampliando-o. Negligenciá-la como campo de estudos provoca consequências desastrosas como, por exemplo, o obscurecimento de determinado capítulo da história de um país. É o caso do colonialismo francês: ao abordar a Geografia clássica sob a ótica "possibilista" das relações sociedade-meio, não se perde somente o engajamento dos geógrafos daquela época com a política, mas a própria história da França é negligenciada no tocante ao empreendimento colonial.

Todavia, por mais incrível que possa parecer, nem sempre somos capazes de alcançar o fato de que a Geografia também faz história. Aprendemos a olhar para o mundo através das paisagens registradas pela pintura e pela fotografia; a habitar o

\footnotetext{
${ }^{31}$ A condição de Estado plurinacional declarada pela República da Bolívia em sua Constituição de 2009, na qual foram incluídas noções oriundas dos povos indígenas no tratamento de questões ambientais e territoriais, é um exemplo de novas práticas geográficas (CONSTITUCIÓN POLÍTICA DEL ESTADO, 2009). Seria ainda uma contraposição ao Estado westphaliano, conforme sugerem alguns estudiosos do Direito? (AFONSO; MAGALHÃES, 2011). Em argumentação um tanto quanto apressada e, a nosso ver, fora da realidade vivida pelos países da América Latina, o antropólogo Arjun Appadurai aprofunda a crítica à ordem westphaliana e indica como as diásporas do século XX e a globalização dissociaram, na prática, território e Estado-Nação. Segundo ele, vivemos uma era de "processos geográficos pós-nacionais” caracterizada por "afiliações translocais” configuradoras de "mapas de fidelidade que atravessam fronteiras e uma política de co-presença territorial não exclusiva” (APPADURAI, 1997, p. 37, 40 e 41 [1996], respectivamente). No início dos anos de 1990, o diplomata francês Jean-Marie Guéhenno sugerira algo parecido, destacando o fim das nações, da política e do território em um mundo global pós-Guerra Fria (GUÉHENNO, 1999 [1993]). Leituras desta natureza foram contestadas por Rogério Haesbaert (2007 [2004]).

${ }^{32}$ Inspiramo-nos aqui nas reflexões sobre tradução apontadas por Homi K. Bhabha (2010 [1989]).
} 
espaço como um tecido costurado por limites e regiões. A natureza e o território vieram a ser os fundamentos dos Estados Nacionais. Em síntese, narrativas históricas são eminentemente geográficas - conforme podemos observar com toda evidência em pesquisas realizadas por não geógrafos (BRAUDEL, 1996 [1967]; 1989 [1986]; CHAUÍ, 2000; MURARI, 2009; BRIZUELA, 2012).

Outro sintoma visível e problemático da desvalorização dos geógrafos diante do processo histórico diz respeito ao silêncio para com seus autores considerados clássicos. Infelizmente não sabemos sobre eles como deveríamos, pois, diferente da Sociologia e da Antropologia, temos pouco apreço por nosso legado. Os geógrafos clássicos parecem ser ultrapassados, fora de moda, não ter nada a dizer nem sobre o passado, nem sobre o presente. Simplesmente esquecemos que a atual configuração territorial tem a ver com suas intervenções pretéritas, além, claro, de nossa concepção de Geografia ser deles tributária.

Tal situação é, no mínimo, contraditória, pois desde antes da institucionalização da disciplina, quando "geógrafos” ligados à Engenharia e à Cartografia integraram as missões militares de Napoleão ao Egito (GODLEWSKA, 1989), passando pela apologia ao colonialismo promovida pelos geógrafos universitários, a Geografia vem deixando sua marca na "fronteirização" do mundo. Em virtude da sua bem sucedida participação nas conferências de paz após a Guerra que ocorreu entre 1914-1918, o geógrafo norte-americano Isaiah Bowman tornou-se "conselheiro geográfico" do presidente Franklin Delano Roosevelt durante a Segunda Guerra Mundial, encontrando-se inclusive com Winston Churchill em 1944 para tratar de assuntos geopolíticos. Além disso, também foi um dos idealizadores da Organização das Nações Unidas e diretor da American Geographical Society (cf. PRÉVÉLAKIS, 1994; SMITH, 1984; 2004). No decorrer da Primeira Guerra Mundial, Albert Demangeon integrou, ao lado de Lucien Gallois, Vidal de La Blache e Emmanuel De Martonne, a Comission de géographie que, subordinada ao Service géographique de l'armée, redigia exposições sucintas sobre sítio, situação e redes de transporte e comunicação de determinados países associados à guerra. Em 1917, juntamente com Paul Vidal de La Blache, Emmanuel de Martonne, Lucien Gallois, Augustin Bernard, Jean Brunhes e Maurice Fallex, Demangeon também participou do Comité d'Études - encarregado pelo governo de examinar a nova configuração das fronteiras europeias e organizar a Conferência de Paz de 1919 (BOLINEAU, 2001; ARRAULT, 2002).

Em uma conjuntura de crise do nacionalismo e do Estado Nacional, Demangeon e De Martonne refletiriam ainda sobre os prós e os contras da criação da PanEuropa $^{33}$ (MUET, 1996; PARKER, 1987). Igualmente, merecem destaque as

33 A propósito, vale a pena recuperar Les conditions géographiques d'une Union Européenne. Fédération européenne ou Ententes régionales? Publicado por Demangeon nos Annales d'histoire économique et sociale, em 1932, trata-se de texto atualíssimo onde estão presentes os fundamentos da União Européia. Com a crise do imperialismo, ele sugere que a Europa olhe para si própria. 
atuações da Société Géographique de Paris e da Royal Geographical Society. Fundadas respectivamente em 1821 e em 1830, ambas forneceram seus ricos acervos cartográficos à inteligência de seus países no desenrolar da Primeira Guerra Mundial. Sob a ótica militar propriamente dita, cumpre destacar a Geographical Section of the General Staff - ligada ao British War Office - e o Service Géographique de l'Armée - ligado ao Ministère de la Guerra (HEFFERNAN, 2002).

Não se trata de multiplicar os exemplos. Eles são suficientes para ressaltarmos que esquecer a história do pensamento geográfico ou abordá-la apenas como história das idéias é desconhecer os usos sociais, políticos, econômicos, militares, culturais e simbólicos dos saberes geográficos. É decifrar o processo histórico apartado das fronteiras erguidas ao redor do mundo pelo status quo. É falha grave, já que significa, em última instância, evitar nosso engajamento e compromisso políticos.

Raciocinando à luz da epistemologia, negligenciar a história do pensamento geográfico nada mais é que a expressão de nossa frágil concepção de historicidade. Eis um problema de monta: a Geografia mais apagou que incorporou seu passado. Algo a impele fortemente para o presente e para o futuro, como se seu legado tivesse pouca ou nenhuma relevância ou precisasse ser esquecido. Embora o panorama tenha mudado nos últimos vinte anos, o que ocorre é uma perceptível ausência de, na falta de expressão mais adequada, um “arquivo geográfico”. Não lidamos com Alexander von Humboldt, Alfred Hettner, Carl Ritter, Friedrich Ratzel, Karl Haushofer, Élisée Reclus, Paul Vidal de La Blache, Albert Demangeon, Maximilien Sorre, John Halford Mackinder, Isaiah Bowman e Carl Sauer da maneira crítico-construtiva com que sociólogos e antropólogos comumente abordam Max Weber e Émile Durkheim, Bronislaw Malinowski e Gilberto Freyre. Enquanto tais campos travam um diálogo crítico, construtivo e aberto à inspeção com suas referências intelectuais, os geógrafos têm optado por subvalorizar seus clássicos. Decerto não estamos a insinuar uma memória historicista, apropriada pura e simplesmente em prol da tradição, mas, sim, um arquivo permanentemente aberto à inspeção que possibilite vislumbrarmos nosso passado sem receios. Tal movimento significará uma pausa reflexiva que nos levará adiante, um momento de inflexão absolutamente imprescindível, uma crítica ao atual estado de coisas. Em suma, uma oposição à presentificação e ao

Criticando a divisão internacional do trabalho praticada pela Grã-Bretanha, levanta uma série de aspectos da integração econômica europeia (mercado exportador, ausência de infraestrutura, crédito para os países mais pobres, desigualdades sócio-econômicas) e termina por defender acordos regionais a uma federação (DEMANGEON, 1932). Esta análise liga-se àquela realizada há uma década, quando Demangeon assinalara os efeitos econômicos e geopolíticos da I Guerra Mundial sobre a Europa, que culminaram no endividamento e na perda de hegemonia para os Unidos e o Japão. O título da obra é eloquente: Le déclin de l'Europe (DEMANGEON, 1920). 
esquecimento que a ideologia consumista e determinadas vertentes pós-modernas insistem em nos fazer aderir.

Para tanto, é preciso enfrentar, com a maior transparência possível as inúmeras aproximações dos geógrafos de outrora com temas ásperos como geopolítica, colonialismo e nacionalismo, pois somente o conhecimento de nossos "arquivos" e de nossa memória produzirá as condições necessárias para superarmos a tradição geográfica colonial (BASSIN, 1987; 1987a; NICOLAS-OBADIA; GUANZINI, 1987; NICOLAS-OBADIA, 1988; SANGUIN, 1988; ASHWORTH; ASHWORTH, 2004; SINGARAVÉLOU, 2008; KEARNS, 2010; SINGARAVÉLOU, 2011; 2011a).

\section{Conclusão}

Boa parte das vezes as narrativas disciplinares tentam soar como único caminho possível no exame da história de um campo do saber. Uma vez revestida de tintas epistemológicas, conceitos e ideias referentes a autores, escolas e correntes de pensamento, tudo parece cooperar para que a Geografia perca de vista sua intervenção no mundo dos fenômenos, sua relevância histórica, seu impacto social. Daí a necessidade de frisarmos a dimensão política inscrita na história e na escritura da Geografia, tendo como base um olhar crítico a incidir sobre a cultura de fronteira por ela suscitada.

As Ciências Humanas são responsáveis pela composição de imagens e de representações que, todavia, estão longe de pertencerem apenas ao plano das ideias. Elas se materializam e se concretizam no cotidiano sob os mais diferentes aspectos. Nossos valores e visão de mundo são, em parte, construídos pelas Ciências Humanas, e não é incomum que alguns deles se tornem práticas autoritárias de poder e de controle. No que tange à Geografia, ela forja espaços e duas de suas representações mais eloquentes: mapas e fronteiras. Ela é projeção e imagem do espaço moderno. Portanto, a Geografia é, por essência, política, pois uma de suas tarefas principais é criar e retalhar espaços. Ela articula escalas as mais longínquas produzindo um enredo cuja referência é o próprio mundo. Sim, a concepção de espaço difundida pela Geografia sustenta uma história universal, e sua força ideológica consiste precisamente no fato de que nem sempre logramos conceber outra história. A monotopia subjugou a utopia. Assim, tempo e espaço cristalizaram-se em uma narrativa que apresenta o progresso tecnológico, o desenvolvimento econômico capitalista e os Estados Nacionais Territoriais como feições geográficas inevitáveis da história da humanidade.

Entretanto, não existe narrador capaz de prescindir da experiência territorial na qual ele está imerso. Toda epistemologia é gerada em um determinado lugar, ou seja, em uma dada cultura, e é incontornavelmente dependente dela no sentido de elucidar o mundo sob certos referenciais. Ciente disso, adotar esta visão passa por recuperar a história da Geografia e, no mesmo ato, desconfiar dela. Reescrevê-la 
sob novos alicerces? Isto pode ser realizado, dentre outros caminhos, através do diálogo com a contribuição pós-colonial, cujos esforços têm mostrado ser possível dizer o mundo de maneira diferente - e o faz lançando mão de argumentos e noções plenos de Geografia. Fronteira é um deles. Subvertê-la de sua acepção hegemônica é vital na utopia por outra escrita e outra prática geo-históricas.

Até o presente momento, a crítica dos geógrafos deu-se com magnitude no terreno da economia política e do capitalismo, o que, inútil esclarecer, foi e continua sendo de enorme relevância. Contudo, talvez ela precise atentar mais para a constituição política da disciplina, pois, como esboçamos aqui, tal aspecto atravessa toda a história da Geografia. Ademais, os rumos assumidos pela ciência geográfica no século XXI dependerão diretamente de um contínuo e profundo exame de seu passado. Descuidar deste elemento, abrindo mão da tarefa de descobrir outras trajetórias e, consequentemente, um presente e um futuro distintos, parece ser o caminho mais curto para uma visão distorcida e equivocada do que foi, do que é e do que a Geografia pode ser.

\section{Bibliografia}

AFONSO, Henrique W.; MAGALHÃES, José L. Q. de. (2011). O Estado plurinacional da Bolívia e do Equador: matrizes para uma releitura do Direito Internacional moderno. Revista Brasileira de Direito Constitucional (RBDC), $\mathrm{n}^{\mathrm{0}} 17$, jan./jun.

AL-BARGHOUTI, Tamin. (2013) Entrevista. Jornal O Globo, Caderno Prosa \& Verso, 27 de abril. p. 5.

ALBUQUERQUE JR., Durval M. de. (2009 [1999]) A invenção do Nordeste e outras artes. São Paulo: Cortez.

ANDERSON, Benedict. (2008 [1983]) Comunidades imaginadas. São Paulo: Companhia das Letras.

APPADURAI, Arjun. (1997 [1996]) Soberania sem territorialidade. Notas para uma Geografia pós-nacional. Novos Estudos Cebrap, nº 49, nov.

ARRAULT, Jean-Baptiste. (2007) Penser à l'échelle du Monde. Histoire conceptuelle de la mondialisation en géographie (fin du XIXe siècle/entre-deuxguerres). Université Paris I, Thèse de doctorat de géographie.

ASHWORTH, G. J., ASHWORTH, L. M. (2004) Ratzel and the British Empire: imperialism and the illusion of state power. Paper to symposium Friedrich Ratzel 1904-2004, Leibnitz Institute University of Leipzig.

BASSIN, Marc. (1987a) Friedrich Ratzel (1844-1904). Geographers: Biobibliographical Studies, vol. 11.

BASSIN, Marc. (1987) Imperialism and the nation state in Friedrich Ratzel's political geography. Progress in human geography, 11. 
BASSIN, Marc. (1987a) Race contra space: the conflict between german Geopolitik and National Socialism. Political Geography Quaterly, vol. 6, n 2, april.

BENJAMIN, Walter. (2005 [1940]) Sobre o conceito de história. In: LÖWY, Michel. Walter Benjamin: aviso de incêndio. Uma leitura das teses "Sobre o conceito de história”. Campinas: Boitempo.

BERDOULAY, Vincent. (1995 [1981]) La formation de l'école française de géographie. Paris: Éditions du CTHS.

BESSE, Jean-Marc. (2005) La géographie dans le mouvement des sciences au tournant du siècle. Colloque Autour de 1905: Élisée Reclus - Paul Vidal de La Blache. Le géographe, la cité, le monde. Montpellier, Université Paul Valéry, 5 juillet.

. (2003) Les grandeurs de la Terre. Aspects du savoir géographique à la Renaissance. Paris: ENS Éditions.

BHABHA, Homi K. (2010 [1990]) DissemiNação. O tempo, a narrativa e as margens da nação moderna. In: O local da cultura. Belo Horizonte: Editora UFMG.

. (2010 [1989]) O compromisso com a teoria. In: O local da cultura. Belo Horizonte: Editora UFMG.

BOULINEAU, Emmanuelle. (2001) Um géographe traceur de frontières: Emmanuel de Martonne et la Roumanie. L'espace géographique, ${ }^{\circ} 4$.

BRAUDEL, Fernand. (1997 [1941-1944]) Géohistoire: la société, l'espace et le temps. In: Les ambitions de l'histoire. Édition établie et présentée par Roselyne de Ayala et Paule Braudel. Paris: Éditions de Fallois.

. (1996 [1967]) Civilização material, economia e capitalismo: séculos XVXVIII. Volume 1: As Estruturas do Cotidiano. São Paulo: Martins Fontes.

(1989 [1986]) A identidade da França: o espaço e a história. Vol. 1. São Paulo: Globo.

BRIZUELA, Natalia. (2012) Fotografia e império. Paisagens para um Brasil moderno. São Paulo: Companhia das Letras/Instituto Moreira Salles.

BROC, Numa. (1974) L’établissement de la géographie en France: diffusion, institutions, projets (1870-1890). Annales de Géographie, 459, sept/oct.

- (1977) La géographie française face à science allemande (1870-1914). Annales de Géographie, 473, jan/fév.

BUTTIMER, Anne. (1980 [1973]) Sociedad y medio en la tradición geográfica francesa. Barcelona: Oikos-Tau.

CALHOUN, Craig. (2008) O nacionalismo importa. In: DOYLE, Don H., PAMPLONA, Marco A. (orgs.). Nacionalismo no Novo Mundo. A formação dos Estados-Nação no século XIX. Rio de Janeiro: Record.

CAPEL, Horacio. (1981) Filosofía e ciencia en la geografía contemporánea. Barcelona: Barcanova. 
CASTRO-GÓMEZ, Santiago. (2005 [2000]) Ciências sociais, violência epistêmica e o problema da "invenção do outro". In: LANDER, Edgardo (org.). A colonialidade do saber. Eurocentrismo e Ciências Sociais: perspectivas latinoamericanas. Buenos Aires: CLACSO.

CHAKRABARTY, Dipesh. (2008 [2000]) Provincializing Europe. Postcolonial thought and historical difference.Princeton/Oxford: Princeton University Press.

CHAUÍ, Marilena. (2000) Brasil: mito fundador e sociedade autoritária. São Paulo: Perseu Abramo.

CLAVAL, Paul. (2000) Hérodote and the French left. In: DODDS, Klaus; ATKINSON, David (eds.). Geopolitical traditions. A century of geopolitical thought. London and New York: Routledge.

Nathan.

(1998) Histoire de la géographie française de 1870 à nos jours. Paris:

(1994) Playing with mirrors: the British Empire according to Albert Demangeon. In: GODLEWSKA, Anne; SMITH, Neil (eds.). Geography and empire. Oxford: Blackwell.

CLAYTON, Daniel. (2011) La formation de la géographie à l'époque des Empires. Géographie et cultures [En ligne], 80.

. (2008) Le passé colonial/impérial et l'approche postcoloniale de la géographie anglophone. In: SINGARAVÉLOU, Pierre (dir.) L'empire des géographes. Géographie, exploration et colonisation (XIX-XX siècle). Paris: Belin.

CLERC, Pascal. (2011) Tous colonialistes? Les géographes français et l’idéologie coloniale. Communication au colloque Quand l'injustice crée le droit: le procès des insurgés de Cayenne à Nantes en 1931, Archives départamentales de LoireAtlantique, 14 et 15 avril.

CONSTITUCIÓN Política del Estado. (2009) República de Bolivia, Asamblea Constituyente, Honorable Congreso Nacional. Texto aprobado en el referéndum constituyente de enero de 2009.

CRUSH, Jonathan. (1994) Post-colonialism, de-colonization, and geography. In: GODLEWSKA, Anne; SMITH, Neil (eds.). Geography and empire. Oxford: Blackwell.

D’ALESSANDRO, Cristina. (2003) Un regard sur la géographie coloniale française. Annales de Géographie, ${ }^{\circ} 631$.

DEMANGEON, Albert. (1940) La colonisation blanche sous les tropiques. Annales de Géographie. pp. 278-279.

(1939) Géographie politique, à propos de l'Allemagne. Annales de Géographie, $\mathrm{n}^{\circ} 272$.

. (1932) Géographie politique. Annales de Géographie, nº 229. 
(1932a) Les conditions géographiques d'une Union Européenne. Fédération européenne ou ententes régionales? Annales d'Histoire Économique et Sociale, $\mathrm{n}^{\mathrm{0}}$ 17, 30 septembre.

. (1923) L’Empire britannique. Étude de géographie coloniale. Paris: Armand Colin.

. (1920) Le déclin de l'Europe. Paris: Armand Colin.

(1907) Colonisation. In: . Dictionnaire de Géographie. Paris: Armand Colin.

DEPREST, Florence. (2009) Géographes en Algérie (1880-1950). Savoirs universitaires en situation coloniale.Paris: Belin.

DÖPCKE, Wolfgang. (1999) A vida longa das linhas retas: cinco mitos sobre as fronteiras na África Negra. Revista Brasileira de Política Internacional, 42 (1).

DOSSE, François. (2007 [1992]) A convidada de útima hora: a geografia desperta para a epistemologia. In: . História do estruturalismo: o canto do cisne, de 1967 a nossos dias. Vol. II. Bauru: Edusc.

DRIVER, Félix. (1992) Geography's empire: histories of geographical knowledge. Environment and planning D, Society and Space, vol. 10.

DUBOIS, Marcel. (1893) Leçon d'ouverture du cours de géographie coloniale. Annales de Géographie, IIIe année, $\mathrm{n}^{\circ} 10$.

DUSSEL, Enrique. (2005 [2000]) Europa, modernidade e eurocentrismo. In: LANDER, Edgardo (org.). A colonialidade do saber. Eurocentrismo e Ciências Sociais: perspectivas latino-americanas. Buenos Aires: CLACSO.

ESCOLAR, Marcelo. (1998) Geografía francesa y politica alemana: Camille Vallaux (1908-1912). Cuadernos de Geografía, Bogotá, Departamento de Geografía, $n^{\circ} 4$.

. (1993) Crítica do discurso geográfico. São Paulo: Hucitec.

FARINELLI, Franco. (2000) Friedrich Ratzel and the nature of (political) geography. PoliticalGeography, 19.

FEBVRE, Lucien. (1962 [1936]) Cartographie régionale. In: . Pour une histoire à part entière. Paris: SEVPEN.

- (1962 [1934-36]) L’Atlas de France du Comité National de Géographie.

In: . Pour une histoire à part entière. Paris: SEVPEN.

. (1962 [1934]) Cartographie régionale allemande. In: . Pour une histoire à part entière. Paris: SEVPEN.

(1962 [1929]) Cartographie de la géopolitique. In: . Pour une histoire à part entière. Paris: SEVPEN.

. (1962 [1928]) Frontière: le mot et la notion. In: Pour une histoire à part entière. Paris: SEVPEN.

. (1991 [1922]) A terra e a evolução humana. Introdução geográfica à história. $2^{a}$ ed. Lisboa: Cosmos. 
(1962 [1908]) Frontière: limites et divisions territoriales de la France en 1789. In: Pour une histoire à part entière. Paris: SEVPEN.

FERREIRA, André V. B. (2009) A reinvenção da Geografia. Tese (Doutorado em Geografia) - Programa de Pós-graduação em Geografia, Instituto de Geociências, Universidade Federal de Minas Gerais.

FERRETTI, Federico. (2013a) Regard hétérodoxe sur le Nouveau Monde: la géographie d'Élisée Reclus et l'extermination des amérindiens. Journal de la Société des Américanistes, 99-1.

. (2013) They have the right to throw us out: Élisée Reclus’New Universal Geography. Antipode: a radical journal of geography, 1.

- (2011) The correspondence between Élisée Reclus and Pëtr Kropotkin as a source for the history of geography. Journal of historical geography, 37.

FOUCAULT, Michel. (1984) Des espaces autres. Architecture, Mouvement, Continuité, vol. 5

. (1979) Microfísica do poder. Rio de Janeiro: Graal.

(1976) Questions à Michel Foucault sur la géographie. Hérodote, $\mathrm{n}^{0} 1$.

. (2004 [1971]) A ordem do discurso. São Paulo: Loyola.

GODLEWSKA, Anne. (1999) Geography unbound: French geographic science from Cassini to Humboldt. Chicago: University of Chicago Press.

. (1989) Traditions, crisis and new paradigms in the rise of the modern french discipline of Geography 1760-1850. Annals of the Association of American Geographers, vol. 79, $\mathrm{n}^{\circ}$ 2, jun.

GRATALOUP, Christian. (2009) L'invention des continents. Comment l'Europe a découpé le monde. Paris: Larousse.

GROSFOGUEL, Ramon. (2010 [2008]) Para descolonizar os estudos de economia política e os estudos pós-coloniais: transmodernidade, pensamento de fronteira e colonialidade global. In: SANTOS, Boaventura de S., MENESES, Maria P. (orgs.). Epistemologias do Sul. $6^{\text {a }}$ ed. São Paulo: Cortez.

GUÉHENNO, Jean-Marie. (1999 [1993]) O fim da democracia. Rio de Janeiro: Bertrand Brasil.

HAESBAERT, Rogério. (2007 [2004]) O mito da desterritorialização. Do "fim dos territórios” à multiterritorialidade. $3^{\mathrm{a}}$ ed. Rio de Janeiro: Bertrand Brasil.

. (2012) PEREIRA, Sergio N.; RIBEIRO, Guilherme. Vidal, Vidais. Textos de geografia humana, regional e política. Rio de Janeiro: Bertrand Brasil.

HARLEY, John B. (2009 [1988]) Mapas, saber e poder. Confins, 5.

HARVEY, David. (2000) Reinventing geography. New Left Review 4, july-august. HAUSHOFER, Karl. (1998 [1945]) Defense of german geopolitics.In: Ó TUATHAIL, Géaroid; DALBY, Simon; ROUTLEDGE, Paul (eds.). The geopolitics reader. London and New York: Routledge. 
. (1998 [1925]) Why Geopolitik? In: ÓTUATHAIL, Géaroid; DALBY, Simon; ROUTLEDGE, Paul (eds.). The geopolitics reader. London and New York: Routledge.

HEFFERNAN, Michael. (2002) The politics of the map in the early twentieth century.Cartography and geographical information science, vol. 29, $n^{\circ} 3$.

(2000) Fin de siècle, fin du monde? On the origins of European geopolitics, 1890-1920. In: DODDS, Klaus; ATKINSON, David (eds.). Geopolitical traditions. A century of geopolitical thought. London and New York: Routledge.

HEIDEGGER, Martin. (1976 [1966]). Já só um Deus nos pode ainda salvar. Der Spiegel, $\mathrm{n}^{\circ} 23$.

HESKE, Henning. (1987) Karl Haushofer: his role in German geopolitics and in Nazi politics. Political geography quarterly, vol. 6, n 2, april.

. (1986) Political geographers of the past III. German geographical research in the Nazi period: a content analysis of the major geography journals, 19251945. Political geography quarterly, vol. 5, no 3, july.

HISSA, Cássio E. V. (2002) A mobilidade das fronteiras: inserções da Geografia na crise da modernidade. Belo Horizonte: Editora UFMG.

HITLER, Adolf. (1998 [1927]) Eastern orientation or Eastern policy? In: Ó TUATHAIL, Géaroid; DALBY, Simon; ROUTLEDGE, Paul (eds.). The geopolitics reader. London and New York: Routledge.

HOBSBAWM, Eric. (1990) Nações e nacionalismo desde 1780: programa, mito e realidade. $3^{\mathrm{a}}$ ed. São Paulo: Paz e Terra.

HOLDAR, Sven. (1992) The ideal state and the power of geography. The life-work of Rudolf Kjellén. Political geography quaterly, vol.11, nº 3, may.

KEARNS, Gerry. (2010) Geography, geopolitics and Empire. Transactions of the Institute of British Geographers, 35.

KERSHAW, Ian. (2010 [2008]) Hitler. São Paulo: Companhia das Letras.

KJELLÉN, Rudolf. (1921) America's unity. The Living Age, july, 23.

17. . (2010 [2008]) What inspires a League of Nations. The Living Age, april,

KROPOTKIN, Piotr. (2014 [1913]) As guerras e o capitalismo. GEOgraphia, UFF, vol. 16, $\mathrm{n}^{0} 32$.

(1986 [1885]) O que a geografia deve ser. Seleção de textos, Associação dos Geógrafos Brasileiros, ${ }^{\circ} 13$.

LACOSTE, Yves. (1988 [1976]) A geografia - isso serve, em primeiro lugar, para fazer a guerra. Campinas: Papirus.

LANDER, Edgardo (org.). (2005 [2000]) A colonialidade do saber. Eurocentrismo e Ciências Sociais: perspectivas latino-americanas. Buenos Aires: CLACSO.

LIVINGSTONE, David. (1992) The geographical tradition. Episodes in the history of a contested enterprise.London/New York: Routledge. 
LOISEAUX, Olivier (dir.). (2007) Trésors photographiques de la société de géographie. Paris: Bibliothèque Nationale de France/Glénat.

MACKINDER, Halford J. (1942) Geography, an art and a philosophy. Geographical Association, vol. 27, $\mathrm{n}^{\circ}$ 4, december.

. (1911) The teaching of geography from an imperial point of view, and the use which could and should be made of visual instruction. Geographical Teacher, 6.

. (2004 [1904]) The geographical pivot of history. The geographical journal, vol. $170, \mathrm{n}^{\circ} 4$, dec.

MALDONADO-TORRES, Nelson. (2010 [2004]) A topologia do ser e a geopolítica do conhecimento. Modernidade, império e colonialidade. In: SANTOS, Boaventura de S.; MENESES, Maria P. (orgs.). Epistemologias do Sul. 6 a ed. São Paulo: Cortez.

MASSEY, Doreen. (2008 [2005]) Pelo espaço. Uma abordagem política da espacialidade. Rio de Janeiro: Bertrand Brasil.

MBEMBE, Achille. (2001) At the edge of the world: boundaries, territoriality, and sovereignty in Africa. In: APPADURAI, Arjun (ed.). Globalization. Durhan \& London: Duke University Press.

MIGNOLO, Walter D. (2009) Epistemic desobedience, independent thought and de-colonial freedom. Theory, Culture \& Society, vol. 26 (7-8).

MIGNOLO, Walter D. (2008) Novas reflexões sobre a "Idéia da América Latina": a direita, a esquerda e a opção descolonial. Caderno $C R H$, v.21, n ${ }^{\circ} 53$, maio/ago.

MIGNOLO, Walter D. (2003 [2000]) Histórias locais/projetos globais: colonialidade, pensamento liminar e saberes subalternos. Belo Horizonte: Editora da UFMG.

MORAES, Antonio C. R. (1999 [1981]) Geografia: pequena história crítica. 17 ed. São Paulo: Hucitec.

. (2002 [1986]) A gênese da geografia moderna. $2^{a}$ ed. São Paulo: Hucitec.

MUET, Yannick. (1996) Les géographes et l'Europe. L'idée européenne dans la pensée géopolitique française de 1919 à 1939. Genève: Euryopa, Institut européen de l’Université de Genève.

MURARI, Luciana. (2009) Natureza e cultura no Brasil (1870-1922). São Paulo: Alameda.

MURPHY, David T. (1994) Space, race and geopolitical necessity: geopolitical rhetoric in german colonial revanchism, 1919-1933. In: GODLEWSKA, Anne; SMITH, Neil (eds.). Geography and empire. Oxford: Blackwell.

NICOLAS-OBADIA, Georges. (1988) Paul Vidal de la Blache et la politique. Bulletin de l'association géographique française, 4.

; GUANZINI, Catherine. (1987) Géographie et Politique: Paul Vidal de La Blache. Eratosthene-Meridien, 1. 
NUNES, João A. (2010) O resgate da epistemologia. In: SANTOS, Boaventura de S.; MENESES, Maria P. (orgs.). Epistemologias do Sul. $6^{a}$ ed. São Paulo: Cortez. Ó TUATHAIL, Géaroid. (2005 [1996]) Critical geopolitics. The politics of writing global space. London: Routledge.

PARKER, Geoffrey. (2000) Ratzel, the French School and the birth of alternative geopolitics.Political Geography 19. pp. 957-969.

(1987) French geopolitical thought in the interwar years and the emergence of the European idea. Political geography quaterly, vol. 6, april.

PORTO-GONÇALVES, Carlos W. (2010) A reinvenção dos territórios: a experiência latino-americana e caribenha. In: COELHO NETO, Agripino S.; SANTOS, Edinusia M. C.; SILVA, Onildo A. da (orgs.). (GEO) grafias dos movimentos sociais. Feira de Santana: UEFS Editora.

; RIBEIRO, Guilherme. (2011) Partilhando versões sobre ciência e política. In: HISSA, Cássio E. V. Conversações: de artes e de ciências. Belo Horizonte: Editora da UFMG.

PROJETO Nova Cartografia Social da Amazônia. Disponível em: $<$ www.novacartografiasocial.com/index.php>. Acessado em 29/09/2013.

PRÉVÉLAKIS, George. (1994) Isaiah Bowman, adversaire de la Geopolitik. L'Espace géographique, $\mathrm{n}^{\circ} 1$.

QUIJANO, Anibal. (2010) Colonialidade do poder e classificação social. In: SANTOS, Boaventura de S.; MENESES, Maria P. (orgs.). Epistemologias do Sul. $6^{\text {a }}$ ed. São Paulo: Cortez.

RAFFESTIN, Claude; LOPRENO, Dario; PASTEUR, Yvan. (1995) Géopolitique et histoire. Lausanne: Payot.

RATZEL, Friedrich. (1995) Le sol, la société et l’État. L'année sociologique, 1898-1899. pp.1-14.

. (1898a) Studies in political areas.III. The small political area. The american journal of sociology, vol. 4, $\mathrm{n}^{\circ} 3$, nov. p.366-379.

. (1898) Studies in political areas II.Intellectual, political, and economic effects of large areas.The american journal of sociology, vol. 3 , $n^{\circ} 4$, jan.

. (1897) Studies in political areas.The political territory in relation to earth and continents. The american journal of sociology, vol. $3, n^{\circ} 3$, nov.

. (1990 [1896]) As leis do crescimento espacial dos Estados. In:

Textos selecionados. Org. de Antonio C. R. Moraes. São Paulo: Ática.

RECLUS, Élisée. A Grã-Bretanha e as colônias de povoamento. In: [1908]) Textos selecionados. Org. de Manuel C. de Andrade. São Paulo: Ática. . (1894) Quelques mots d’histoire. La société nouvelle, 10e année, CXIX, novembre.

- (1883) Colônias de exploração: governo e administração da Índia. In: . Textos selecionados. Org. de Manuel C. de Andrade. São Paulo: Ática. 
- (1985 [s/d]) Origem da família, das classes sociais e do Estado. In: . Textos selecionados. Org. de Manuel C. de Andrade. São Paulo: Ática. (1985 [s/d a]) Evolução da sociedade e da civilização. In: Textos selecionados. Org. de Manuel C. de Andrade. São Paulo: Ática.

REICHERT, Dagmar. (1992) On boundaries. Environment and Planning D: Society and Space 10. pp. 87-98.

REIS, José C. (2005) História \& teoria: historicismo, modernidade, temporalidade e verdade. Rio de Janeiro: FGV.

RHEIN, Catherine. (1982) La géographie, discipline scolaire et/ou science sociale? (1860-1920). Revue française de Sociologie, Paris, XXIII.

RIBEIRO, Guilherme. A imagem como concepção de mundo. Resenha de L'invention des continents. Comment l'Europe a découpé le monde, de Christian Grataloup. Continentes (UFRRJ), n.1 (2012).

RIBEIRO, Guilherme. Narrativas em conflito: considerações sobre o campo história do pensamento geográfico. Geografia (Rio Claro), vol. 37 (2012a).

RIBEIRO, Guilherme. Vidal de la Blache, ciência e política: notas a partir do caso africano. Confins [Online], 12 (2011).

RIBEIRO, Guilherme. Território, império e nação: geopolítica em Paul Vidal de la Blache. Revista da Anpege, vol. 6 (2010).

RIBEIRO, Guilherme. La géographie vidalienne et la géopolitique. Géographie et Cultures (2010a).

RIBEIRO, Guilherme. Luta pela autonomia e pelo território: a Geografia e os Estados alemão e francês na virada do século XIX para o século XX. Mercator (UFC), ano VIII, n.15, pp. 19-28 (2009).

RIBEIRO, Guilherme. Para ler geografia ou A geografia segundo Lucien Febvre. Terra Livre, AGB-Nacional, ano 25, vol. 1, n. 32, jan.-jun (2009a).

ROBIC, Marie-Claire (dir). (2006) Couvrir le monde. Un grand XXème siècle de la géographie française. Paris : ADPF.

- (1993) La creación des Annales de Géographie (1891). Estrategia universitaria y geografía humana. Documents d'anàlisi geogràfica, 22.

RYAN, James R. Postcolonial geographies. In: DUNCAN, James S.; JOHNSON, Nuala C.; SCHEIN, Richard H. (eds.). (2004) A companion to cultural geography. Oxford: Blackwell.

. (1994) Visualizing imperial geography: Halford Mackinder and the Colonial Office Visual Instruction Committee, 1902-1911. Ecumene, 1 (2).

SAID, Edward W. (1995 [1993]) Cultura e Imperialismo. São Paulo: Companhia das Letras.

. Orientalismo. O Oriente como invenção do Ocidente. São Paulo: Cia. das Letras.

SANGUIN, André-Louis. (2007 [1978]) Vidal de La Blache et la géographie politique. Bull. Assoc. Géogr. Franç., Paris, 4 (1988). 
SANDNER, Gerhard; RÖSSLER, Mechtild. (1994) Geography and empire in Germany, 1871-1945.In: GODLEWSKA, Anne; SMITH, Neil (eds.). Geography and empire. Oxford: Blackwell.

SANTOS, Douglas. (2002) A reinvenção do espaço: diálogos em torno da construção do significado de uma categoria. São Paulo: UNESP.

SANTOS, Boaventura de S.; MENESES, Maria P. (orgs). (2010) Epistemologias do Sul. $6^{\text {a }}$ ed. São Paulo: Cortez.

(2010) Para além do pensamento abissal: das linhas globais a uma ecologia de saberes. In: SANTOS, Boaventura de S.; MENESES, Maria P. (orgs.). Epistemologias do Sul. $6^{\text {a }}$ ed. São Paulo: Cortez.

. (2007 [2000]) A crítica da razão indolente: contra o desperdício da experiência. $6^{\mathrm{a}}$ ed. São Paulo: Cortez.

. (2010 [1987]) Um discurso sobre as ciências. 10ª ed. São Paulo: Cortez.

SANTOS, Milton. (1978) Por uma geografia nova. Da crítica da geografia a uma geografia crítica. São Paulo: Hucitec/Edusp.

. (2002 [1996]) A natureza do espaço. Técnica e tempo. Razão e emoção. São Paulo: Edusp.

SCHMITT, Carl. (2014 [1950]) O nomos da Terra no direito das gentes do jus publicum europaeum. Rio de Janeiro: Contraponto/Editora PUC-Rio.

SIBEUD, Emmanuelle. (2008) La Société de géographie de l'Afrique occidentale française (1907-1908): un modèle périmé? In: SINGARAVÉLOU, Pierre (dir.) L'empire des géographes. Géographie, exploration et colonisation (XIX-XX siècle). Paris: Belin.

- (2011a) L’Empire des géographes. L’enseignement de la géographie coloniale. In: . Professer l'Empire. Les "sciences coloniales” en France sous la III République. Paris: Publications de la Sorbonne.

SINGARAVÉLOU, Pierre. (2011) The institutionalisation of "colonial geography” in France, 1880-1940. Journal of historical geography, 37.

(dir.). (2008) L'empire des géographes. Géographie, exploration et colonisation (XIX-XX siècle). Paris : Belin.

SMITH, Neil; GODLEWSKA, Anne. (1994) Introduction: critical histories of geography. In: (eds.). Geography and empire. Oxford: Blackwell.

. (2004) American Empire. Roosevelt's geographer and the prelude to globalization. Berkeley/Los Angeles/London: University of California Press.

(1984) Isaiah Bowman: political geography and geopolitics. Political geography quaterly, vol. $3, \mathrm{n}^{0} 1$, jan.

SOJA, Edward. (1993 [1989]) Geografias pós-modernas. A reafirmação do espaço na teoria social crítica. Rio de Janeiro: Jorge Zahar.

SOUBEYRAN, Olivier. (1997) Imaginaire, science et discipline. Paris:

L'Harmattan. 
SPIVAK, Gayatri C. (2010 [1985]) Pode o subalterno falar? Belo Horizonte: Editora UFMG.

SUREMAIN, Marie-Albane de. (1999) Métamorphoses d'un continent. L'Afrique des Annales de Géographie de 1919 au début des années 1960. Cahiers d'Études africaines, 153, XXXIX-1.

TESCHKE, Benno. (2006) The metamorphoses of European territoriality.A historical reconstruction. In: BURGESS, Michael; VOLLARD, Hans (eds.). State territoriality and european integration. London: Routledge.

TODOROV, Tzvetan. (2012) Os inimigos íntimos da democracia. São Paulo: Companhia das Letras.

- (2010 [2008]) O medo dos bárbaros: para além do choque das civilizações. Petrópolis: Vozes.

VIDAL DE LA BLACHE, Paul. (2012 [1910]). A carta internacional do mundo ao milionésimo. In: HAESBAERT, Rogério; NUNES PEREIRA, Sergio; RIBEIRO, Guilherme (orgs.). Vidal, Vidais. Textos de Geografia humana, regional e política. Rio de Janeiro: Bertrand Brasil.

. (2007 [1903]) La France. Tableau géographique. In: RIOUX, Jean-Pierre. Tableaux de la France. Michelet, Duruy, Vidal de La Blache et Bruno. Paris: Omnibus.

(1911) Les confins algero-marrocains, d'après le livre de Augustin Bernard. Annales de Géographie, année XX, nº 114.

. (1911a) Les genres de vie dans la géographie humaine. Premier article. Annales de Géographie, ano XX, n 111.

. (1911b) Les genres de vie dans la géographie humaine. Deuxième article. Annales de Géographie, ano XX, n 112.

WALTER, François. (2004) Les figures paysagères de la nation. Territoire et paysage en Europe (XVIe-XXe siècle). Paris: Éditions de l'EHESS.

WERLEN, Benno. (2012) Entrevista. Boletim campineiro de Geografia, v.2, no 3. . (2000) Regionalismo e sociedade política. GEOgraphia, UFF, ano II, $\mathrm{n}^{\circ} 4$, dez.

. (1993) Society, action and space: an alternative human geography. London: Routledge.

WOLFF, Denis. (2005) Albert Demangeon (1872-1940). De l'école communale à la chaire en Sorbonne, l'itinéraire d'un géographe moderne. Thèse de Doctorat, Université Panthéon-Sorbonne - Paris I. 